\title{
Towards the Use of Land Use Legacies in Landslide Modeling: Current Challenges and Future Perspectives in an Austrian Case Study
}

\author{
Raphael Knevels ${ }^{1, *(\mathbb{D}}$, Alexander Brenning ${ }^{1}\left(\mathbb{D}\right.$, Simone Gingrich ${ }^{2} \mathbb{}{ }^{\circ}$, Gerhard Heiss ${ }^{3}$, Theresia Lechner ${ }^{2}$, \\ Philip Leopold ${ }^{3}$, Christoph Plutzar ${ }^{2,4}$, Herwig Proske ${ }^{5}$ and Helene Petschko ${ }^{1}$ \\ 1 Department of Geography, Friedrich Schiller University Jena, 07743 Jena, Germany; \\ alexander.brenning@uni-jena.de (A.B.); helene.petschko@uni-jena.de (H.P.) \\ 2 Department of Economics and Social Sciences, University of Natural Resources and Life Sciences, \\ 1070 Vienna, Austria; simone.gingrich@boku.ac.at (S.G.); t.lechner@mysynergis.com (T.L.); \\ christoph.plutzar@umweltbundesamt.at (C.P.) \\ 3 Center for Low-Emission Transport, AIT Austrian Institute of Technology GmbH, 1210 Vienna, Austria; \\ Gerhard.Heiss@ait.ac.at (G.H.); Philip.Leopold@ait.ac.at (P.L.) \\ 4 Division of Conservation Biology, Vegetation Ecology and Landscape Ecology, University of Vienna, \\ Rennweg 14, 1030 Vienna, Austria \\ 5 Remote Sensing and Geoinformation Department, JOANNEUM RESEARCH Forschungsgesellschaft mbH, \\ 8010 Graz, Austria; herwig.proske@joanneum.at \\ * Correspondence: raphael.knevels@uni-jena.de
}

Citation: Knevels, R.; Brenning, A.; Gingrich, S.; Heiss, G.; Lechner, T.; Leopold, P.; Plutzar, C.; Proske, H.; Petschko, H. Towards the Use of Land Use Legacies in Landslide Modeling: Current Challenges and Future Perspectives in an Austrian Case Study. Land 2021, 10, 954. https://doi.org/10.3390/land10090954

Academic Editors: Matej Vojtek, Andrea Petroselli and Raffaele Pelorosso

Received: 4 August 2021

Accepted: 4 September 2021

Published: 8 September 2021

Publisher's Note: MDPI stays neutra with regard to jurisdictional claims in published maps and institutional affiliations.

Copyright: (c) 2021 by the authors Licensee MDPI, Basel, Switzerland. This article is an open access article distributed under the terms and conditions of the Creative Commons Attribution (CC BY) license (https:// creativecommons.org/licenses/by/ $4.0 /)$
Abstract: Land use/land cover (LULC) changes may alter the risk of landslide occurrence. While LULC has often been considered as a static factor representing present-day LULC, historical LULC dynamics have recently begun to attract more attention. The study objective was to assess the effect of LULC legacies of nearly 200 years on landslide susceptibility models in two Austrian municipalities (Waidhofen an der Ybbs and Paldau). We mapped three cuts of LULC patterns from historical cartographic documents in addition to remote-sensing products. Agricultural archival sources were explored to provide also a predictor on cumulative biomass extraction as an indicator of historical land use intensity. We use historical landslide inventories derived from high-resolution digital terrain models (HRDTM) generated using airborne light detection and ranging (LiDAR), which are reported to have a biased landslide distribution on present-day forested areas and agricultural land. We asked (i) if long-term LULC legacies are important and reliable predictors and (ii) if possible inventory biases may be mitigated by LULC legacies. For the assessment of the LULC legacy effect on landslide occurrences, we used generalized additive models (GAM) within a suitable modeling framework considering various settings of LULC as predictor, and evaluated the effect with well-established diagnostic tools. For both municipalities, we identified a high density of landslides on present-day forested areas, confirming the reported drawbacks. With the use of LULC legacy as an additional predictor, it was not only possible to account for this bias, but also to improve model performances.

Keywords: land use/land cover legacy; airborne LiDAR-based HRDTM; generalized additive model; landslide susceptibility modeling; historical landslide inventory bias; biomass extraction

\section{Introduction}

Landslides pose a threat to human lives and infrastructure. A changing climate and land use/land cover (LULC) alter the landslide risk and thus have societal consequences [1,2]. In Austria, landslides are relevant natural hazards preconditioned by factors such as lithology, geomorphology, tectonic structures and LULC, and are mainly triggered by long-lasting heavy rainfall and rapid snowmelt [3]. Therefore, understanding the factors that increase the chance of landslide occurrence is crucial for spatial planning in the face of ongoing and expected future climate and LULC changes. 
LULC types, and their changes, are reported to have different hydrological and geomechanical effects controlling slope stability [4]. While forest is often considered to stabilize slopes [5], forest harvesting or road construction undercutting slopes may reduce slope stability [6,7]. However, in landslide studies, LULC has often been considered as a static factor representing solely the present-day LULC [8] (i.e., latest available LULC). Recently, more studies have begun to account for historical LULC in landslide analysis, assigning LULC dynamics an important role in explaining landslides [9-12]. Beguería [9] and Persichillo et al. [11] discovered a high landslide susceptibility on abandoned cultivated land, even after revegetation by shrubs or trees in the Spanish Pyrenees and in the Oltrepò Pavese (Italy), respectively. Gariano et al. [10] and Pisano et al. [12] found evidence that land management reduced landslide occurrences in Southern Italy (Calabria and Molise), supporting the importance of LULC changes in spatial planning practice. However, due to the availability of mainly remote-sensing products (aerial or satellite imagery), these landslide analyses were only able to consider historical LULC since the mid-20th century (e.g., since 1954 in [12] or since 1957 in [9]). To the authors' knowledge, only one study used historical cartographic documents as additional sources (e.g., Napoleonic cadastral map) to assess the long-term legacy effects of LULC on mass movements [13].

In general, legacy effects describe the influence of past events or processes on later states, often spanning decades to centuries $[14,15]$. Long-term legacy effects of past LULC have been shown to exist in the context of socio-ecological dimensions such as contemporary forest structure, management and disturbance risk [16] or biodiversity $[17,18]$. For mass movements, Lopez-Saez et al. [13] revealed the potential of historical LULC changes in explaining the paradoxical observation of reduced rockfall hazards despite an increased urban exposure in the Grenoble conurbation since 1850. Especially the forest densification at the upper part of the slope was considered to contribute to the identified decrease in rockfall frequency and energy for volumes up to $5 \mathrm{~m}^{3}$ [13].

For landslide analysis and modeling, landslide inventories are a fundamental source to improve the understanding of the factors that precondition and trigger landslides. In the last decade, low-cost, airborne LiDAR-based high-resolution digital terrain models (HRDTM) became available area-wide for all federal provinces of Austria $(\leq 10 \mathrm{~m} \times 10 \mathrm{~m})$ [19]. Many studies demonstrated the potential of LiDAR HRDTM and its derivatives to identify landslides, and thus to substantially improve conventionally created landslide inventories [20-22], especially underneath the forest cover, where passive remote-sensing sensors are of limited utility [23].

Generally, landslide inventories have an unknown level of incompleteness [24] and thus may be biased. Inventory biases have previously been studied for remotely-sensed, event-based or archival inventories, and can be caused by focusing solely on administrative boundaries, damage reports or on a single triggering event $[25,26]$. While most authors reported the usefulness of LiDAR-derived historical landslide inventories, only few analyzed drawbacks of the data source [26,27]. For example, it is very challenging or even impossible to determine a landslide's exact extent, absolute age, trigger, and potential for reactivation when using only HRDTM derivatives [28,29]. Additionally, according to Petschko et al. [27], forest cover may have a conservation effect on the landslide morphology (i.e., "young" morphology of a "very old" landslide), while landslides may be underrepresented on agricultural land and near infrastructure due to land rehabilitation (i.e., "very young" morphology but no visibility on orthophoto) resulting in a landslide inventory that is substantially biased towards a high landslide density in recently forested areas. Analyzing the effect of systematically incomplete landslide inventories, Steger et al. [26] discovered that landslide susceptibility models emphasized bias-describing predictors (e.g., larger regression coefficients), and as a consequence the bias was directly propagated into the landslide predictions. While Petschko et al. [27] recommended to exclude inventory-biasing observations (i.e., "old" and "very old" landslides) or to drop the bias-describing predictor (i.e., present-day land cover) from modeling, Steger et al. [26] included the bias-describing 
predictor (e.g., forested area) as a random effect and used only the fixed effects to make model predictions.

In this study, we investigated the association between LULC legacies and landslide susceptibility using an airborne LiDAR-derived historical landslide inventory in two municipalities in Austria (Waidhofen an der Ybbs and Paldau). We addressed the following main questions: (i) are long-term LULC legacies important and reliable predictors of landslide susceptibility? And (ii) can LULC legacies help to understand and account for possible inventory biases in modeling present-day landslide susceptibility? Additionally, we analyzed the transferability of landslide models between study areas and the effect of dropping inventory-biasing observations.

For the analysis, we digitized and classified LULC patterns for three-time cuts comprising nearly 200 years using various spatial data sources. In addition, yields and livestock statistics were compiled from archival sources and statistical publications, and summarized as socio-ecological variables reflecting plot-level LULC legacies. For the assessment, we used generalized additive models (GAM) within a modeling framework considering different combinations of LULC legacy implementations while also accounting for land surface variables (e.g., slope angle, etc.) and lithological conditions as possible confounders. We evaluated the effect of LULC legacies using well-established diagnostic tools for model assessment and interpretation.

\section{Materials and Methods}

\subsection{Study Area}

The study was conducted in two municipalities in Austria: Waidhofen an der Ybbs (referred to as Waidhofen) in Lower Austria, and Paldau in Styria. The two municipalities represent different landscapes (Figure 1A,C).

Waidhofen is located in the Ybbstaler Alps from $14^{\circ} 39^{\prime} \mathrm{E} 47^{\circ} 52^{\prime} \mathrm{N}$ to $14^{\circ} 56^{\prime} \mathrm{E} 48^{\circ} 01^{\prime} \mathrm{N}$, covers an area of $131 \mathrm{~km}^{2}$ and has a population of about 13,000 inhabitants [30]. Its elevation rises towards the south with a relative relief of $54-651 \mathrm{~m} / \mathrm{km}^{2}$. In the limestone-dominated south, up to $1205 \mathrm{~m}$ above the Adriatic (m AA) are reached; towards the flysch zone in the north the mountains transition into gentle hills (302 m AA) [31]. In contrast, Paldau lies in the East Styrian Basin with a relative relief of $6-138 \mathrm{~m} / \mathrm{km}^{2}$ (282 to $465 \mathrm{~m} \mathrm{AA}$ ), characterized by unconsolidated sediments of the Neogene to Quaternary period [32]. The municipality is an agriculturally favorable region mainly with corn and pig farming. Paldau has a population of 3000 inhabitants [33], it extends from $15^{\circ} 43^{\prime} \mathrm{E} 46^{\circ} 54^{\prime} \mathrm{N}$ to $15^{\circ} 51^{\prime} \mathrm{E} 46^{\circ} 59^{\prime} \mathrm{N}$ and covers $39 \mathrm{~km}^{2}$.

The geological setting coupled with the characteristic very local, frequent and intense rain events in summertime create conditions that make both study areas particularly prone to landslides of different types and magnitudes [34-36]. In the last decades, landslide occurrences have caused substantial damage to settlements and infrastructure in both study areas $[37,38]$.

\subsection{Data}

This study is based on land surface and landslide data from various sources and at different spatial resolutions. As our target resolution, we used $10 \mathrm{~m} \times 10 \mathrm{~m}$ to account for the dependence of landslide susceptibility on local-scale topography. 

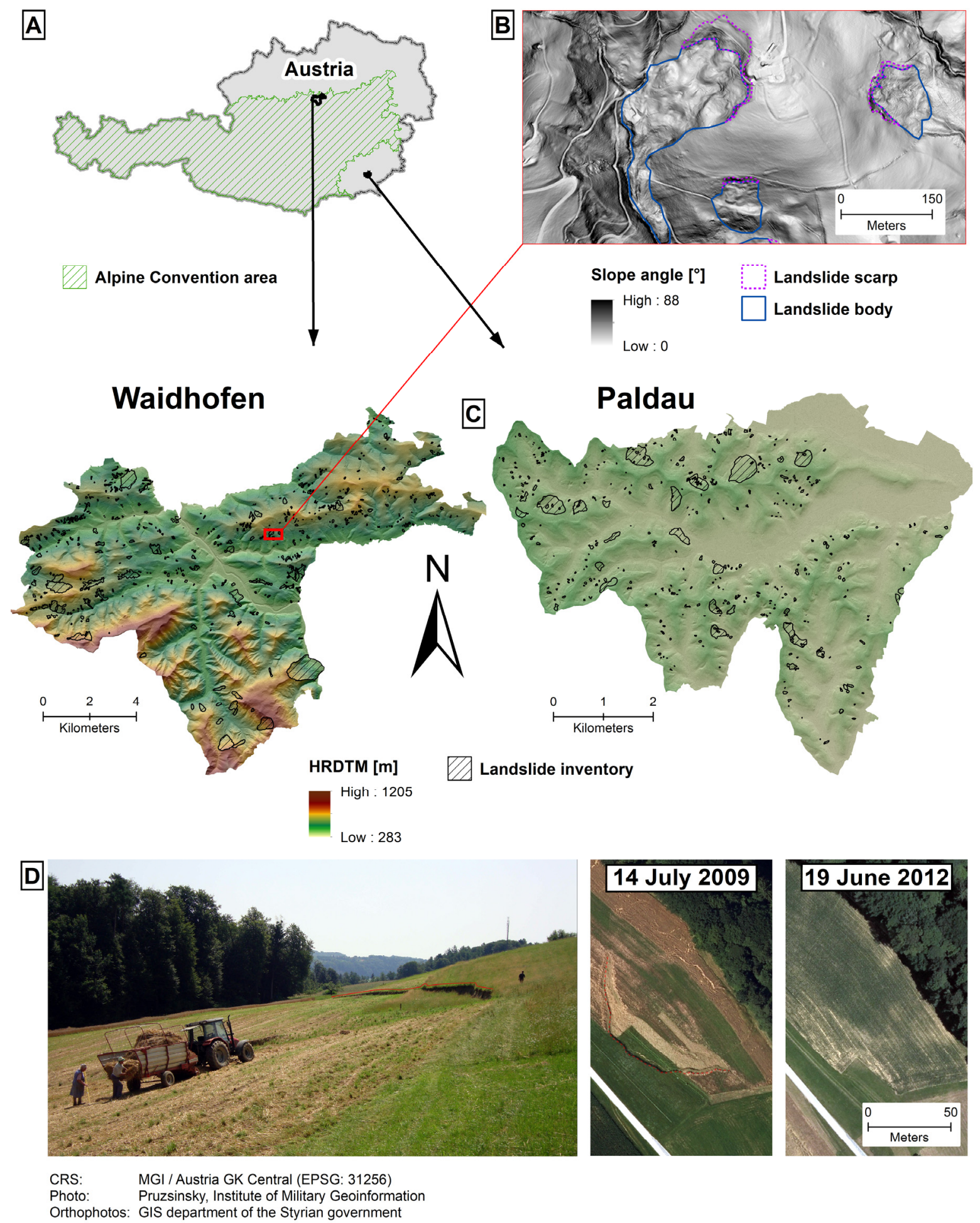

Figure 1. Overview of study area. (A): Location of study areas in Austria. (B): Landslides visible in Waidhofen's slope map (red rectangle in (C)). (C): HRDTM and derived landslide inventory. (D): A landslide on cropland in the district South East Styria, which occurred after an extreme rainfall event in June 2009, and "disappeared" in the following years. Photo taken on 23 July 2009.

\subsubsection{Land Surface Data}

For both study areas, airborne LiDAR-based HRDTMs of $1 \mathrm{~m} \times 1 \mathrm{~m}$ resolution were available, which were provided by the GIS department of the Styrian government for 
Paldau (acquisition year: 2009), and by the provincial government of Lower Austria for Waidhofen (acquisition year: 2017), respectively (Table A1).

Datasets of hydrologic and hydropedologic characteristics were compiled by the Austrian Research Centre for Forests in 2014 for Waidhofen [39] (50 $\mathrm{m} \times 50 \mathrm{~m}$ resolution) and in 2017 for Paldau [40] (100 m $\times 100 \mathrm{~m}$ resolution), respectively, and were made available by the respective federal states. The datasets include information on soil parameters such as soil type, total pore volume, and hydraulic conductivity of the topsoil $(0-20 \mathrm{~cm})$.

Geological basemaps at a 1:50,000 scale were provided by the Geological Survey of Austria for Waidhofen and by the Styrian GIS department for Paldau, respectively. In both geological basemaps, alluvial deposits were corrected in order to match valley floors visible in the HRDTM. Furthermore, we reclassified the geological units into a smaller number of relevant classes. In Waidhofen the reclassification was based on lithology and geomechanical properties which resulted in seven lithological units of (i) alluvial deposits, (ii) talus and glacial deposits, (iii) Inneralpine Neogene, (iv) Klippen zone, (v) flysch zone, (vi) Upper Austroalpine marls, and (vii, reference level) Upper Austroalpine limestone. In Paldau, we specified five geological units based on grain size distribution and age of origin: (i, reference level) Neogene formations with coarse-grained layers, (ii) Neogene formations dominated by fine-grained sediments, (iii) pre-Würmian Pleistocene formations, (iv) Würmian and Holocene sediments, and (v) other units.

\subsubsection{LULC Legacy}

By combining unique historical spatially explicit information on LULC in the two study areas and numerical information on land use intensity, we were able to create information on LULC legacies that could be used as an input in landslide susceptibility modeling. This is, to our knowledge, the first study that uses such a long, multi-temporal and spatially explicit LULC record to better understand regional-scale landslide susceptibility.

To generate this dataset, we collected, digitized and harmonized data depicting different spatial patterns for the years 1820, 1960 and 2015 (Table 1). Our data sources included the Franciscan Cadastre of 1820, aerial photographs of 1960, and aerial orthophotos combined with Integrated Administration and Control System (IACS) data of 2015 ("present-day"). Numerical information on LULC intensity (e.g., agricultural yields and machinery numbers) was collected at communal, district or provincial levels from archival sources and both historical and recent statistics, and was up- or downscaled to match the municipal level. The data sources assigned to a time cut slightly differed in their year of origin between the municipalities (Table 1). The selection of the time cuts was based on characteristic socio-economic framework conditions of the Central European cultural landscape following Bender [41] (i.e., time cuts around 1850, 1914, 1960 and present age) as well as on the availability and temporal proximity of data.

We created a vector GIS database with LULC polygons from these sources using ESRI ArcGIS. We distinguished between forest area, cropland and grassland, and classified the remaining LULC as "settlement and other" (for details refer to Table A2 in the Appendix A). Due to varying data quality $(Q$, Table 1$)$, in the first step, the cadastral maps (1820) and orthophotos (2015) were georeferenced and digitized (EPSG: 32633) since these allowed us to map boundaries between distinct land uses. In a second step, we used these layers as base maps for digitizing the less distinct areas from greyscale aerial photographs (1960). Spatially persistent natural and built structures were kept unchanged for all time cuts. Furthermore, we consistently used a display scale of 1:1000 to keep the digitization error constant. The estimated overall positional error is up to 3-5 $\mathrm{m}$ for $1820,5-10 \mathrm{~m}$ for 1960 , and less than $3 \mathrm{~m}$ for 2015 . 
Table 1. Sources of land use legacy information of at least acceptable spatial and thematic quality identified for the case study areas.

\begin{tabular}{|c|c|c|c|c|c|}
\hline Year & Study Area & Source & Source Holder & $\mathbf{Q}$ & Q-Explanation \\
\hline \multicolumn{6}{|c|}{ Land use and land cover } \\
\hline 1820 & $\begin{array}{l}\text { Wh } \\
\text { P }\end{array}$ & $\begin{array}{l}\text { Maps of Franciscan } \\
\text { Cadastre }\end{array}$ & $\begin{array}{c}\text { Provincial Archive of Lower } \\
\text { Austria } \\
\text { Federal Office for Calibration and } \\
\text { Measurement }\end{array}$ & $\begin{array}{l}++ \\
++\end{array}$ & $\begin{array}{c}\text { Sharp delimitation of utilization } \\
\text { unit }\end{array}$ \\
\hline $\begin{array}{l}1962 \\
1953\end{array}$ & $\begin{array}{l}\text { Wh } \\
\mathrm{P}\end{array}$ & Aerial images & $\begin{array}{l}\text { Federal Office for Calibration and } \\
\text { Measurement }\end{array}$ & $\begin{array}{l}\sim \\
\sim\end{array}$ & $\begin{array}{l}\text { Differentiation based on greyscale } \\
\text { aerial photography }\end{array}$ \\
\hline 2015 & $\begin{array}{l}\text { Wh, } \\
\text { P }\end{array}$ & Orthophotos \& IACS * & Open Data Austria & ++ & $\begin{array}{c}\text { Parcel-sharp delimitation of } \\
\text { arable land and grassland }\end{array}$ \\
\hline \multicolumn{6}{|c|}{ Agricultural yields (cereal and grassland) } \\
\hline 1820 & Wh & $\begin{array}{c}\text { Text records of } \\
\text { Franciscan Cadastre }\end{array}$ & $\begin{array}{c}\text { Provincial Archive of Lower } \\
\text { Austria }\end{array}$ & + & $\begin{array}{c}\text { based on two cadastral } \\
\text { municipalities of Waidhofen }\end{array}$ \\
\hline 1820 & $\mathrm{P}$ & Sandgruber [42] & & $\sim$ & average of Styria \\
\hline 1960 & $\begin{array}{l}\text { Wh, } \\
P\end{array}$ & Agricultural statistics & Statistics Austria Library & ++ & data on municipality level \\
\hline 2015 & $\begin{array}{l}\text { Wh, } \\
\mathrm{P}\end{array}$ & IACS * & Open Data Austria & + & data of farms in municipality \\
\hline \multicolumn{6}{|c|}{ Wood yields } \\
\hline 1820 & Wh & $\begin{array}{c}\text { Text records of } \\
\text { Franciscan Cadastre }\end{array}$ & $\begin{array}{l}\text { Provincial Archive of Lower } \\
\text { Austria }\end{array}$ & + & $\begin{array}{c}\text { based on two cadastral } \\
\text { municipalities of Waidhofen }\end{array}$ \\
\hline 1820 & $\mathrm{P}$ & Gingrich et al. [43] & & $\sim$ & average of Styria \\
\hline 1965 & $\begin{array}{l}\text { Wh, } \\
\mathrm{P}\end{array}$ & Weiss et al. [44] & & $\sim$ & Austrian average \\
\hline 2015 & $\begin{array}{l}\text { Wh, } \\
\mathrm{P}\end{array}$ & Forest inventory & Federal Forest Office & $\sim$ & state averages \\
\hline
\end{tabular}

Wh: Waidhofen, P: Paldau; * Data status of temporal extent of 2016; Quality (Q): ++: high spatial and thematic quality, +: high spatial or thematic quality, $\sim$ : acceptable spatial and thematic quality. Adapted from Knevels et al. [45].

Based on the numerical information, we quantified biomass extraction as yields ( $\mathrm{kg}$ fresh weight per ha and year, $\mathrm{kg} \mathrm{FW/ha/a)} \mathrm{at} \mathrm{the} \mathrm{lowest} \mathrm{possible} \mathrm{administrative} \mathrm{level} \mathrm{and}$ allocated it to cropland, grassland and forests. Biomass extraction represents the output from the agricultural production system and is thus an indicator of the LULC intensity during historical time periods [46]. For the biomass extraction from cropland, we employed the cereal yields as proxy; data on harvest from meadows was collected for grassland yields, and wood extraction was derived from forest yields.

We finally intersected the three vector datasets for 1820, 1960 and 2015 successively to one final file, keeping all available attributes, and converted the result to raster format at the uniform target resolution. Biomass extraction was summed over the time cuts to obtain a cumulative land use intensity (Figure A1 in Appendix A). This is an innovative approach for this socio-ecological indicator in the context of landslide science as other authors calculated cumulative materials flows [47] or greenhouse gas emissions [48] in other application contexts. To avoid artifacts due to geometric inaccuracies inherent in the vector files and from sliver polygons, isolated pixels were identified, and the affected grid cells were excluded from the landslide sampling design described below (see Section 2.2.3). The estimated digitization errors (3-10 $\mathrm{m}$ ) might partly be counteracted by using a target resolution of $10 \mathrm{~m} \times 10 \mathrm{~m}$ (i.e., resolution corresponds to largest estimated error).

The created historical LULC legacy dataset was made publicly available [49].

\subsubsection{Airborne LiDAR-Derived Landslide Inventories}

For both study areas, we derived historical landslide inventories by mapping landslides visible in the HRDTM following the approach proposed by Schulz [22]. We included landslides in earth and debris materials, focusing on the slide type with possible transitions 
to complex slide flows according to the classification scheme by Cruden and Varnes [50]. Landslides were digitized as polygon features also distinguishing between landslide body and scarp (Figure 1B). Selected mapped landslides were inspected in the field for validation, and we corrected the inventory where necessary. In total, in Waidhofen, 621 landslides were mapped, covering 5.31\% of the municipal area, and in Paldau, 418 landslides (4.14\% of the area; Figure 1C; Table A3 in the Appendix A).

Following Hussin et al. [51], we randomly sampled landslide presence points in the landslide scarp area using the recommended 50-m distance constraint, and attributed the point to the corresponding grid cell in our target grid (in total 974 and 559 landslide points in Waidhofen and Paldau, respectively). For sampling non-landslide points, we defined the landslide-free area by excluding the mapped landslides and a surrounding $50-\mathrm{m}$ buffer to account for digitization errors. We furthermore excluded so-called trivial areas-areas considered as not susceptible to landsliding (e.g., floodplains, flat areas) [52]. Isolated grid cells (see Section 2.2.2.) and anthropogenic structures with similar geomorphometric characteristics as landslides (e.g., quarries) were also masked. For the landslide absence locations, we distributed random points in a 1:1 sampling ratio using a minimum nearestneighbor distance of $50 \mathrm{~m}$ to reduce spatial autocorrelation.

\subsection{Methods}

The relationships between LULC legacies and landslide distribution were analyzed using GAMs $[53,54]$ while also accounting for the local topography as an important preparatory factor for landslides [8]. GAMs have become popular in landslide susceptibility studies due to their ability to model nonlinear relationships while allowing for a separate interpretation of additive effects in terms of odds ratios and variable importance [55].

Our analysis was conducted in the free and open source computing environment $R(R$ version 3.5.3) [56]. We used the GAM implementation of the mgcv package [54] and the mlr package [57] as the modeling framework. Furthermore, for terrain analysis we used System for Automated Geoscientific Analysis (SAGA) GIS 6.3.0 [58] through RSAGA [59] and Terrain Analysis Using Digital Elevation Models (TauDEM) 5.3 [60] via R system calls.

For downscaling the input data to the target resolution, we applied bilinear interpolation for resampling using SAGA GIS. However, we acknowledge that we are unable to capture local-scale patterns of geology or soil parameters.

\subsubsection{Landslide Susceptibility Modeling Design}

For landslide susceptibility modeling, we related land surface variables, soil parameters, lithological units and LULC legacies as predictors to landslide occurrences (Table 2 for overview).

Our model design enabled us to explore relationships between LULC legacy and landslide distribution, and to improve the understanding of the potential biases in airborne LiDAR-derived landslide inventories. We created landslide susceptibility models with different sets of input variables: (i) The baseline model 'GAM-Base' excludes LULC legacy variables; for the assessment of the LULC legacy effect, we built (ii) a GAM using the present-day LULC as an additional predictor (GAM-2015), (iii) a GAM based on the LULC legacy information from 1960 to 2015 (GAM-1960), and (iv) a GAM based on the LULC legacy information since 1820 (GAM-1820). Moreover, we tested (v) a GAM using the setting of GAM-2015, but excluding potentially inventory-biasing observations following the recommendations of Petschko et al. [27] (GAM-2015-Masked; i.e., all observations located in continuously forest-covered areas). Furthermore, we allowed modeled landslide occurrences to be dependent on the combined effect of the historical biomass extraction and present-day LULC class rather than modeling LULC legacy variables as additive terms. Thus, the predictor of LULC legacy information in GAM-1820 and GAM-1960 was implemented as a parametric, linear interaction term between the LULC of 2015 and the historical biomass extraction (sum since 1820 or 1960). Moreover, we tested the model's 
transferability between study areas, but excluded predictors that are specific to each area (i.e., lithology).

For both study areas, the airborne LiDAR-derived historical landslide inventory and the created landslide susceptibility models are available as Supplementary Materials.

Table 2. Predictor variables for landslide susceptibility modeling.

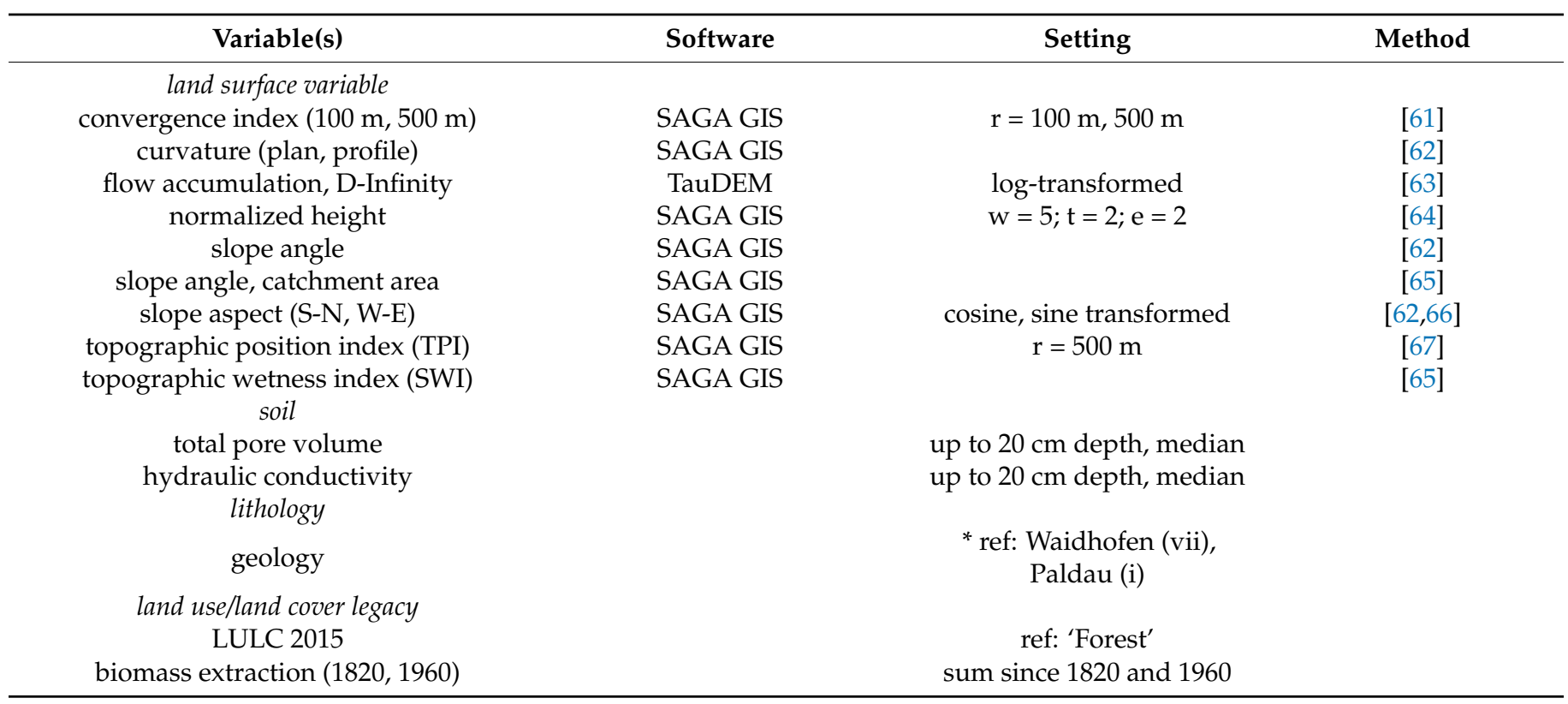

Setting, scale-dependent parameters: r: radius; w,t,e: Parameters in SAGA GIS module Relative Heights and Slope Positions; * ref $=$ reference level (see Section 2.2.1).

\subsubsection{Assessment of the Effect of Land Use Legacy}

The empirical effect of LULC legacy on landslide occurrence was assessed in terms of model performance, variable importance, odds ratios (OR) of the LULC classes, and transformation function plots of the three most important predictor-response relationships.

For the model assessment, we applied a $k$-fold spatial cross-validation (SpCV) to achieve independent test areas and thus a bias-reduced predictive performance as a measure of model generalization [55]. For SpCV, we partitioned the data into five disjoint folds using $k$-means clustering of the coordinates $(k=5)$, and repeated this procedure 100 times. In each repetition, subsequently, four folds were used as training data while the remaining fold was used for validation until each fold was used once for validation (i.e., $k$ models per repetition, 500 models in total). Furthermore, we ensured comparability between the models' performance estimates using identical training and validation data for each study area and repetition.

The area under the receiver operating characteristic curve (AUROC) was computed as the performance measure. The AUROC is a quality measure suitable for binary response data and is a common evaluation tool for landslide susceptibility models [55]. AUROC values lie between 0.5 (no discrimination) and 1.0 (perfect discrimination), and were interpreted following the recommendations of Hosmer et al. [68]. Additionally, differences in model performances were tested using Wilcoxon signed-rank tests $(\alpha=0.05$; $\mathrm{R}$ coin package) $[69,70]$, and $p$-values were adjusted for multiple comparisons according to Benjamini and Hochberg [71].

As a measure of variable importance, we extracted for each variable the mean decrease in deviance explained (mDD, \%) under the consideration of all SpCV models. The $\mathrm{mDD}$ indicates the explanatory contribution of a variable to the overall explained deviance of the corresponding model [72,73]. The higher the $\mathrm{mDD}$ value, the greater is the contribution of a variable, and thus its importance. To compute the $\mathrm{mDD}$, we left the variable of interest out while fixing the remaining smoothing parameters (mgcv::gam sp argument) during 
model (re-)training, and subsequently measured the percentage differences of the deviance explained [73].

Transformation function and OR plots were used to explore the relationships between landslide distribution and the three most important predictors as well as LULC legacy of each model setting. Additionally, we extracted comparative predictor-response relationships reported in studies of the same area $[73,74]$. A transformation function plot shows the predictor-response relationship as a parametric (linear) or non-parametric smoothing function by using the additive structure of a GAM. We visualized predictor-response relationships on the logit scale (i.e., linear predictor scale). An OR indicates the chance that an outcome occurs given a specific exposure, relative to a reference exposure [75]. An OR less than one means an exposure with lower odds of the outcome while an OR higher than one shows an exposure with higher odds of the outcome, while accounting for the other variables in the model; an OR of one is associated with no influence of the exposure [75]. We calculated ORs for the LULC classes with 'forest' as reference level. Additionally, we derived ratios of ORs (rOR) by dividing a model's predictor-response relationships by the corresponding relationship in GAM-Base. rOR enables a more sensitive comparison between models.

\section{Results}

\subsection{LULC Change}

The analysis of almost 200 years of changes in LULC displayed distinct trends in the two municipalities (Figure 2).

Even though forest covered more than one third of the total land area in both case studies throughout the investigation period (Figure 2A), in Paldau, its area decreased by 113.2 ha $(8 \%)$ from 1820 to 2015, while in Waidhofen, the forest area increased by more than 1000 ha (18\%) from 1820 to 2015. In both areas, cropland extent declined while grassland and "settlement and other" expanded. In Waidhofen, in 2015 only 1\% of the area was used as cropland (1820: 26\%), while in Paldau, the share diminished from $43 \%$ to $37 \%$. Areas classified as "settlement and other" increased in Waidhofen more than fivefold from 1820 to 2015 (246 ha to 1431 ha) and in Paldau more than sevenfold (104 ha to 750 ha).

Biomass extraction nearly doubled in both municipalities from one time cut to the next (Figure 2A; Paldau: 4969 to 10,630 to 18,674 kg/ha/a, Waidhofen: 4661 to 8410 to $16,773 \mathrm{~kg} / \mathrm{ha} / \mathrm{a}$ ). Cereal yields increased most strongly in both municipalities (factors 9.8 and 7.9 in Waidhofen and Paldau, respectively). Grassland yields increased less strongly and reached their maximum in 1960. In both study areas, wood extraction declined slightly from 1820 to 1960 (Waidhofen: -6\%, Paldau: -2\%), but it more than doubled from 1960 to 2015 (Waidhofen: $5067 \mathrm{~kg} / \mathrm{ha} / \mathrm{a}$, Paldau: $5667 \mathrm{~kg} / \mathrm{ha} / \mathrm{a})$. In 1820, wood extraction had the largest share in biomass extraction in both municipalities.

The landslide distribution for the different LULC classes and time cuts showed contrasting patterns in Waidhofen and Paldau (Figure 2C). While in Waidhofen, the change pattern in landslide distribution and LULC distribution by LULC category was similar (Figure 2A,C), in Paldau the change pattern showed clear differences. There, $82.4 \%$ of the landslides were located in present-day (2015) forest areas, which also showed the highest landslide frequency ratio (FR) of 2.5 (Figure 2C); in Waidhofen, 42.2\% of the landslides were found in present-day forested areas with a FR of nearly 1. In Waidhofen in 2015, grassland showed the highest FR of 1.14 (Paldau: FR of 0.78). Furthermore, in Paldau, $69 \%$ of the landslides were located in continuously forest-covered areas $(28.7 \%$ for LULC change pattern) and in Waidhofen $20.7 \%$ (27.5\% for LULC change pattern), respectively. In both study areas, landslides were least frequent on present-day cropland (Paldau: FR 0.05, Waidhofen: 0.31). 


\section{A}
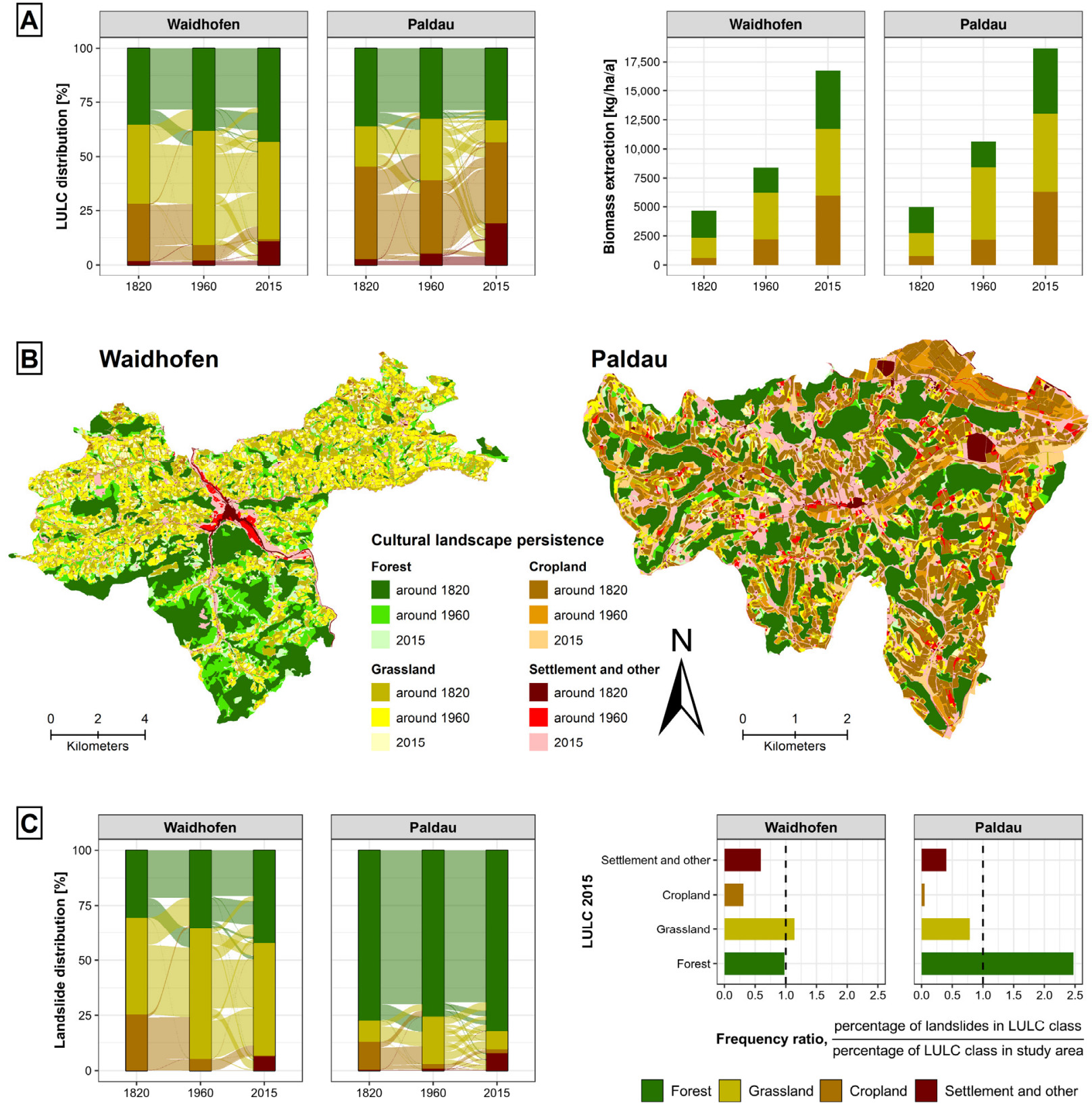

Figure 2. LULC change in the study areas for different time cuts. (A): Changes of LULC patterns (in \%, left) and changes of biomass extraction (in $\mathrm{kg} / \mathrm{ha} / \mathrm{a}$, right). (B): Cultural landscape persistence maps showing persistent historical structures in present-day LULC. (C): Landslide distribution for different LULC patterns (in \%) and their changes (left), and landslide frequency ratios for the LULC pattern in 2015 (right).

\subsection{LULC Legacy Effects on Landslide Occurrence}

\subsubsection{Model Performance and Transferability}

We applied SpCV with the AUROC as performance measurement to gain information on the model's capabilities to discriminate landslides from non-landslides observations. The performance assessment showed distinct differences between the study areas (Figure 3, Table A4 in the Appendix B). 

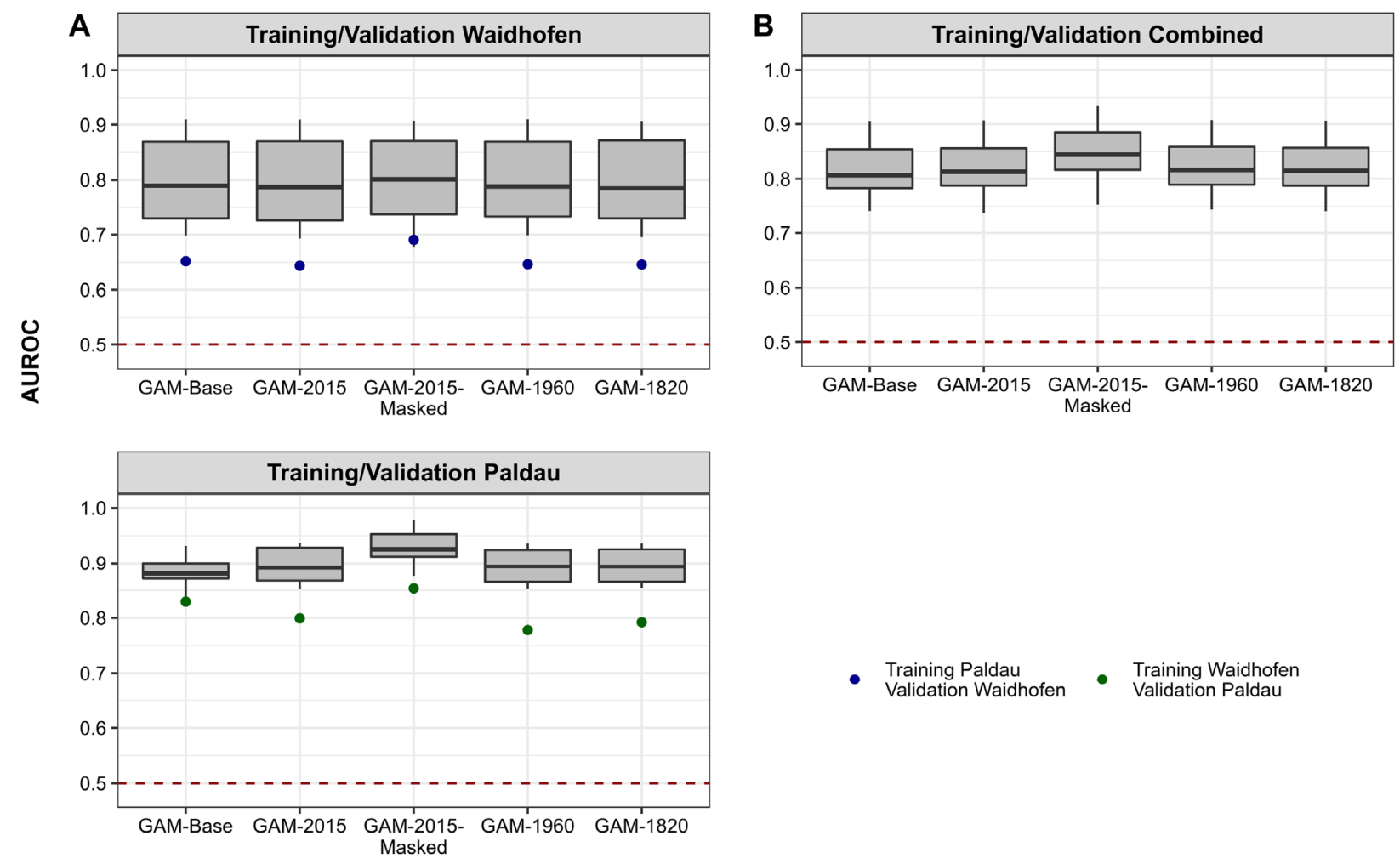

Models

Figure 3. Model performance in SpCV and transferability assessment. (A): Study-area specific SpCV and transferability estimates. (B): SpCV estimates using the combined data from both municipalities.

For Waidhofen the median AUROC (mAUROC) in SpCV ranged between 0.78 for GAM-1820 and 0.80 for GAM-2015-Masked, i.e., acceptable to excellent discrimination capabilities. In contrast, in Paldau, GAM-Base had the lowest mAUROC of 0.88 and GAM2015-Masked the highest $\mathrm{mAUROC}$ of 0.93, i.e., excellent to outstanding discrimination. AUROC estimates for Waidhofen were substantially more variable than for Paldau (interquartile ranges, IQR, 0.13 to 0.14 versus 0.03 to 0.06 ). Model transfer to the other study area resulted in a strong drop in model performance, with a decrease of $0.11-0.14$ for model transfer to Waidhofen and 0.05-0.12 in Paldau. As in SpCV, GAM-2015-Masked performed best (Waidhofen: 0.69, Paldau: 0.85), followed by GAM-Base (Waidhofen: 0.65, Paldau: 0.83 ) in both study areas.

In the performance assessments for the combined data, the mAUROC and IQR values of the combined validation data fall in between the estimates of Paldau and Waidhofen (Figure 3B, Table A4 in the Appendix B). GAM-Base had the lowest mAUROC of 0.81 and GAM-2015-Masked the highest mAUROC of 0.84 .

Regarding the effect of LULC legacy predictors on the performance, for Paldau the performance estimates were marginally, but yet significantly higher with the inclusion of legacy information (order of significant " $<$ " and non-significant " $=$ " differences in AUROCs: GAM-Base < GAM-1960 < GAM-1820 = GAM-2015 < GAM-2015-Masked, Table A5 in the Appendix B). However, for Waidhofen, such a tendency was not identifiable (GAM-2015 < GAM-1820 = GAM-Base < GAM-1960 < GAM-2015-Masked, Table A5 in the Appendix B). Furthermore, for both study areas the landslide model excluding observations located in continuously forest-covered areas (i.e., GAM-2015-Masked) showed the highest estimates in SpCV (combined and non-combined data) and transferability assessment.

\subsubsection{Variable Importance}

The assessment of variable importance showed differences in the variable ranking of the study areas, although slope angle was shared as a top-tier predictor (Figure 4, Table A6 
in the Appendix B). In Waidhofen, the top three ranks were identical across all settings: 1. slope angle (mDD 7.45-8.63\%), 2. lithology ( $\mathrm{mDD} 3.72-6.38 \%)$, and 3. plan curvature (mDD 2.09-2.83\%). In Paldau and across all settings, four different variables occurred in the top three ranks: slope angle (mDD 4.38-7.68\%), profile curvature (mDD 3.05-6.37\%), slope aspect (S-N, mDD 3.94\%), and a LULC legacy variable (LULC 2015 or LULC legacy 1820/1960, mDD 3.64-3.92\%). In all models, slope angle was the most important variable, except for Paldau's GAM-2015-Masked, where profile curvature was more important (mDD 6.37\%).

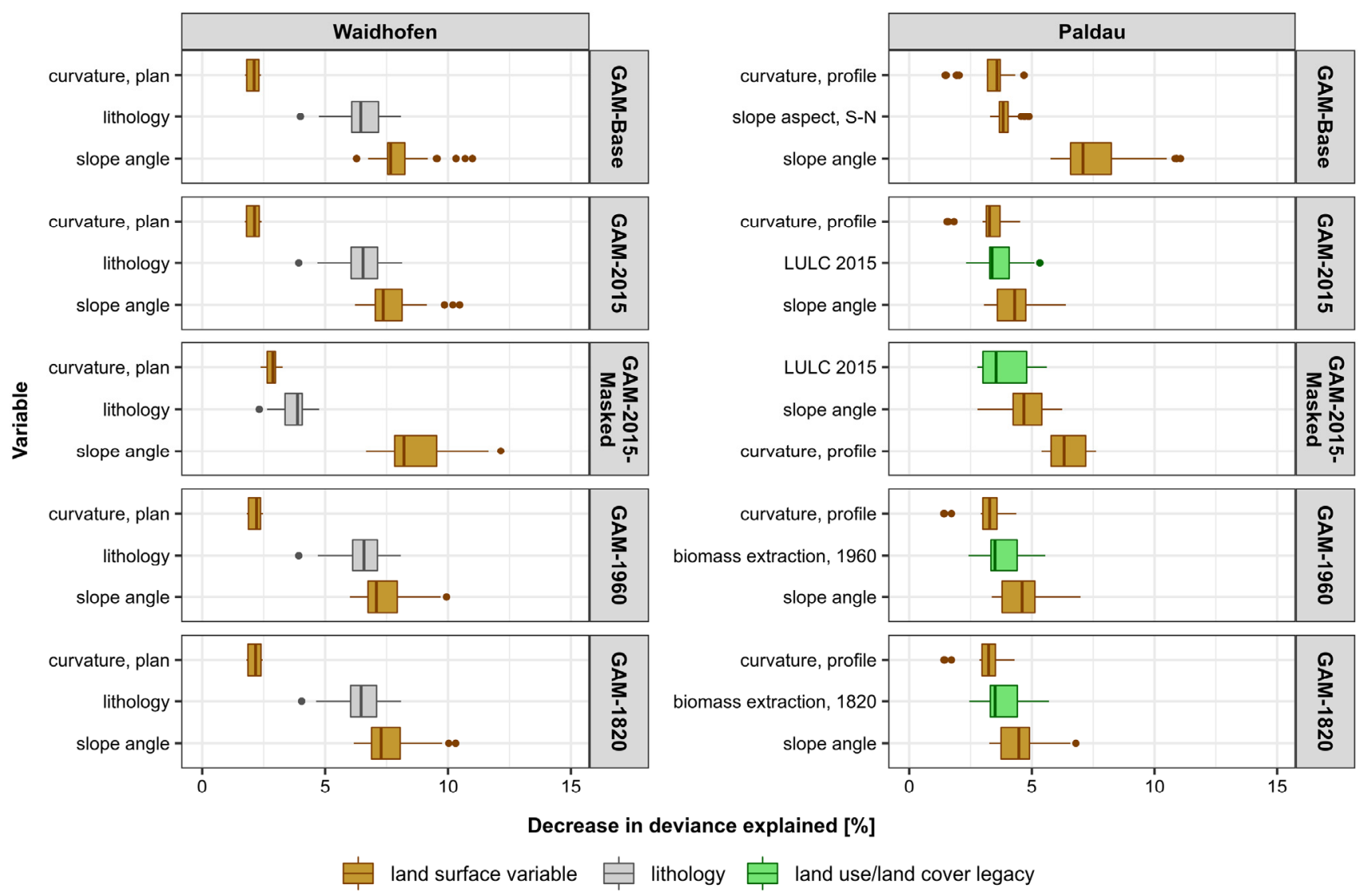

Figure 4. The three most important variables in terms of decrease in deviance explained [\%]. Refer to Table A6 in the Appendix B for an overview of variable importance for all predictor variables.

The top-ranked variable was always a land surface variable, specifically slope angle and in one setting profile curvature (Table A6 in the Appendix B). Soil variables were less important with a highest rank of 11 with $0.62 \% \mathrm{mDD}$ in Waidhofen (hydraulic conductivity in GAM-2015-Masked), and of 7 with $1.3 \% \mathrm{mDD}$ in Paldau (hydraulic conductivity in GAM-2015-Masked), respectively. LULC legacy variables were less important in Waidhofen (mDD 0.26-1.07\%), while for Paldau, they showed a high mDD of 3.64-3.92\%. Lithology, in contrast, was only important in Waidhofen (mDD 6.34-6.38\%; Paldau: 0.25-0.39\%).

\subsubsection{Predictor-Response Relationships}

In both study areas, based on the transformation function plots in logit scale, we found a general agreement on the predictor-response relationships among all model settings, except for the GAM-2015-Masked (Waidhofen: Figure A2, Paldau: Figure A3). However, some differences in the predictor-response relationships for the three most important variables could be identified (Figure 5). 


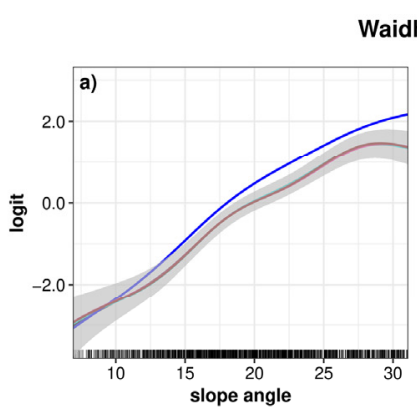

Waidhofen
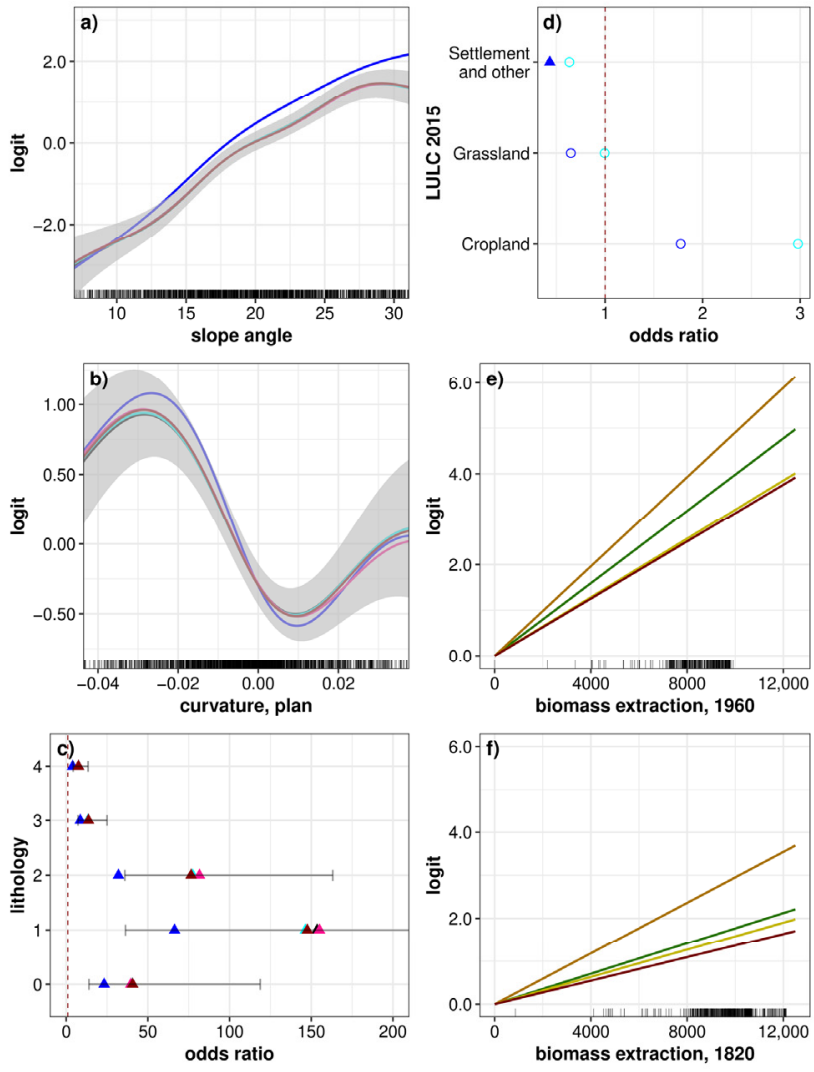

Model

- GAM-Base - GAM-2015 - GAM-2015-Masked — GAM-1960 - GAM-1820

- GaM-Base - GAM-2015 - GAM-2015-Masked - GAM-1960 • GAM-1820

Predictor

- - not significant - significant

$\circ$ not significant $\boldsymbol{\Lambda}$ significant

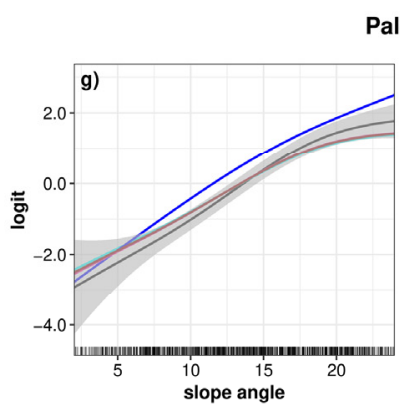

Paldau
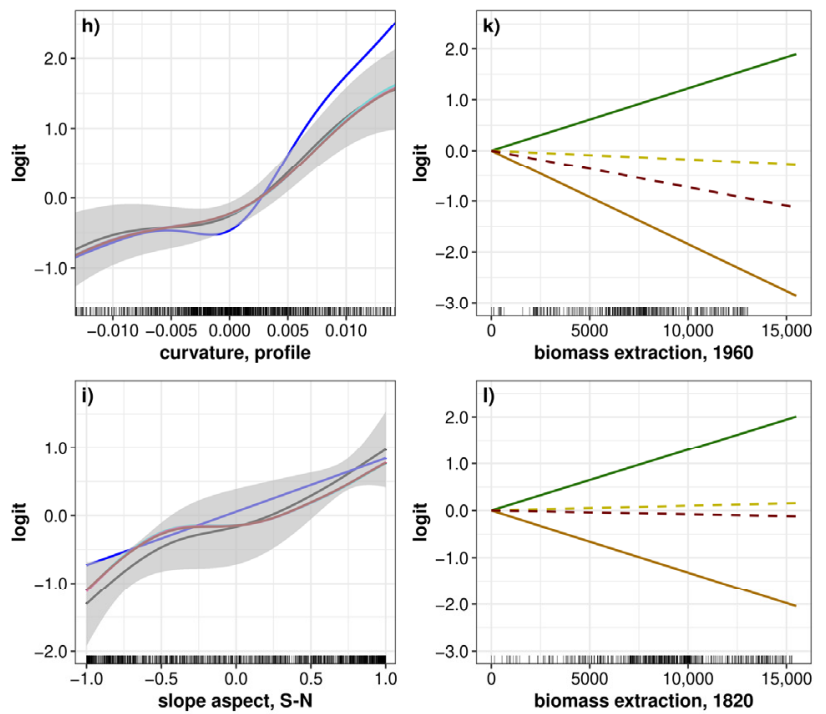

Land use/land cover

- Forest - Grassland

- Cropland - Settlement and other

Figure 5. Comparison of predictor-response relationships of the three most important predictors (left column, (a-c) and $(\mathbf{g}-\mathbf{i}))$ and the LULC legacy variables (right column, $(\mathbf{d}-\mathbf{f})$ and $(\mathbf{j}-\mathbf{1})$ ) for each study area. Grey: 95\% Bayesian credible interval of GAM-Base. Lithological units in Waidhofen: Reference unit: 'Upper Austroalpine limestone', 0: talus and glacial deposits, 1: Inneralpine Neogene, 2: Klippen zone, 3: flysch zone, 4: Upper Austroalpine marls. Note: the y axes are plot-dependent, and the $x$ axes of non-parametric transformation functions are limited to the 5 th to 95 th percentile range.

In both study areas, the chance of landslide occurrence was higher on steeper slopes. Among the model settings, the predictor-response relationship of GAM-Masked-2015 indicated the comparatively highest rOR compared to GAM-Base (e.g., for $15^{\circ}$, Paldau: 1.4, Waidhofen: 1.6). Minor differences of the other models in reference to GAM-Base were mostly at lower and upper quartiles of the value ranges (Figure 5a,g), but fell within its 95\% Bayesian credible interval.

In Waidhofen, for the variable plan curvature, the chance of landslide occurrence was higher on concave than on convex surfaces, but without substantial differences between the models (Figure 5b). Regarding the variable lithology (Figure 5c), each lithological unit showed a higher chance of landslide occurrences relative to Upper Austroalpine limestone (e.g., GAM-Base: OR of 13 for flysch zone). However, among the model settings, the rORs of GAM-Masked-2015 were generally lower by a factor of 0.6 , and fell partially outside the Bayesian credible interval of GAM-Base.

In Paldau, for the variable profile curvature, the chance of landslide occurrence was lower on concave than on convex surfaces (Figure $5 \mathrm{~h}$ ). Substantial differences between the models were identifiable only for GAM-2015-Masked on convex surfaces with a curvature greater than $0.005 \mathrm{~m}^{-1}$ (e.g., landslides were 1.3 times more likely relative to GAM-Base). Among the model settings, south-exposed slopes were less susceptible to landslides than north-exposed slopes, with only marginal differences between models (Figure 5i). 
Regarding the LULC variables, in Waidhofen LULC 2015 was significant only in the GAM-2015-Masked setting for "settlement and other" with an OR of 0.43 relative to forest areas (Figure 5d). Using additionally the biomass extraction as LULC legacy interaction term (i.e., GAM-1960 and GAM-1820), the predictor was significant and showed a higher chance of landslide occurrence with higher biomass extraction for each LULC class (Figure 5e,f). Compared to forest areas, landslides were more likely on cropland and less on grassland and "settlement and other". However, using the long-term legacy in GAM-1820, the contrast relative to forest areas showed higher ORs for cropland (e.g., for $10,000 \mathrm{~kg} \mathrm{FW} / \mathrm{ha} / \mathrm{a}$ : OR of 2.95 for GAM-1820 and of 2.53 for GAM-1960), but lower OR for grassland (OR of 0.83 for GAM-1820 and of 0.46 for GAM-1960) and "settlement and other" (OR of 0.67 for GAM-1820 and of 0.43 for GAM-1960) compared to GAM-1960.

In Paldau, for the variable LULC 2015 in GAM-2015 and GAM-2015-Masked, all LULC classes were significant terms and also showed a similar pattern with minor differences with respect to forest area (reference level; Figure 5j): For GAM-2015, the chance of landslide occurrence on cropland was only 0.07 times as high as in forest areas (OR of 0.06 for GAM2015-Masked), 0.32 times as high on grassland (OR of 0.33 for GAM-2015-Masked), and 0.26 times as high on "settlement and other" (OR of 0.25 for GAM-2015-Masked). Including the biomass extraction as LULC legacy interaction term (i.e., GAM-1960 and GAM-1820; Figure $5 \mathrm{k}, 1)$, for both models, the coefficients of grassland and "settlement and other" were not significant anymore, while with a higher biomass extraction the chance of landslide occurrences on cropland was lower (e.g., for 10,000 kg FW/ha/a: OR of 0.16 for GAM-1960 and of 0.27 for GAM-1820) and higher on forest areas (OR of 3.4 for GAM-1960 and of 3.7 for GAM-1820), respectively. Using the long-term legacy in GAM-1820, the ORs of the LULC classes relative to forest areas were generally lower compared to GAM-1960 (e.g., for 10,000 kg FW/ha/a on cropland: OR of 0.05 for GAM-1960 and of 0.07 for GAM-1820).

We extracted reported relationships of comparative studies, in which the landslide dates were known (for Paldau: event-based landslide inventory of southeast Styria in [73]) or the relative landslide age could be approximated (Waidhofen: remotely-sensed landslide inventory based on [21] used e.g., by [74]). For the land surface variables, we generally found a good match in the shape of the predictor-response relationships in both study areas (Figure 6), with the exception of slope aspect (S-N) in Paldau. Contrary to our results, in Knevels et al. [73] the predictor slope aspect was less influential with south-exposed slopes being slightly more susceptible to landsliding than north-exposed slopes.

Regarding the LULC variables, for Waidhofen, Steger et al. [74] reported that landslides were 1.7 to 2.0 times more likely on arable land or pastures compared to forests, while in our study, LULC was only significant when biomass extraction was included (i.e., GAM-1960 and GAM-1820). For southeast Styria, Knevels et al. [73] found non-forest areas more than three times as susceptible to landsliding as forest areas $(\mathrm{OR}>3.6)$. Yet, in Paldau's GAM-2015 and GAM-2015-Masked, we found contrasting results (OR $<0.33$ outside forest). 

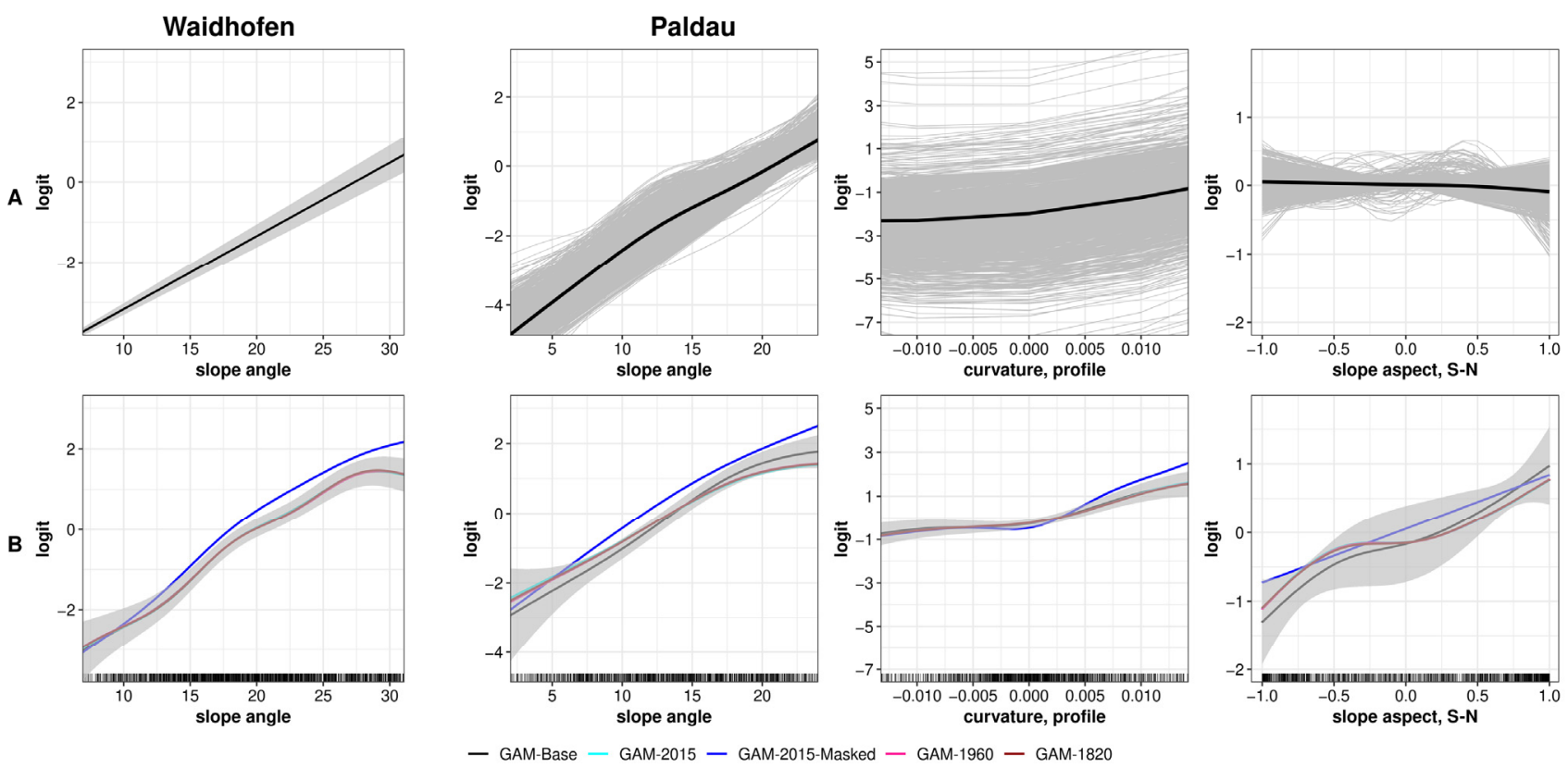

Figure 6. Comparison of predictor-response relationships between event-based landslide and historical LiDAR-derived landslide inventories. (A): Event-based inventory of Waidhofen (left, Table 1 in [74]) and southeast Styria (right, [73]). (B): Historical LiDAR-derived inventory of Waidhofen (left) and Paldau (right). Note: the logit scale is variable-dependent, the intercept for slope angle in Waidhofen was artificially set, and the $\mathrm{x}$ axes are limited to the 5th to 95th percentile range.

\section{Discussion}

\subsection{Initial Objective: Effect of LULC Legacy on Modeling and Biases}

We were able to successfully link the historical LULC characteristics covering a period of almost 200 years in two Austrian municipalities to landslide occurrences identified in an airborne LiDAR-derived HRDTM. The established landslide susceptibility models showed performances with acceptable to outstanding discrimination capabilities, confirming the proposed modeling approach. Landslide models including LULC legacy predictors had significantly higher (for Paldau) or at least equal (for Waidhofen) performances compared to a reference model without LULC (GAM-Base, Table A5 in the Appendix B), demonstrating the potential of LULC legacies for explaining landslide susceptibility today.

The use of LULC legacies may improve the understanding of LULC dynamics and landslide occurrences. The LULC legacy categories were generally more susceptible to landsliding with a higher biomass extraction (excluding cropland in Paldau; Figure 5e,f,k,l). In particular, present-day forested areas previously used for agricultural activities were more prone to landsliding than continuously forested areas, confirming findings for less extensive historical time periods by Beguería [9] and Persichillo et al. [11]. Thus, the effect of LULC legacies on landslide occurrences might be a good explanation of contradictory empirical observations such as landslide events in forests [23]. Additionally, for Waidhofen, we conclude that forest areas are more susceptible to landsliding than grassland, after accounting for biomass extraction. While Goetz et al. [7] reported that forest harvesting may temporally lead to open or semi-open forest types and thus reduced slope stability due to different soil hydrological and mechanical conditions (e.g., reduced rainfall interception and root cohesion), Tasser et al. [76] found managed grassland to be significantly less erodible than abandoned areas. However, we acknowledge that potentially landslide mitigating land management strategies are not incorporated in the analysis, and that the difference between forest and grassland may also be related to inventory biases.

Inventory biases are a known issue in landslide modeling $[25,26]$. We suggest that the identified substantial difference in the predictor-response relationship for LULC compared to other studies, is due to the underlying airborne LiDAR-derived historical landslide inventory. In particular, we assume that in Paldau, the high number of landslides in 
continuously forest-covered areas (69\%, FR of 2.5 in 2015) can be explained by an inventory bias, which ultimately produces biased predictor-response relationships (OR of 0.33 for outside forest relative to forest areas vs. OR of $>3.6$ in Knevels et al. [73]). A bias was also detectable in Waidhofen's inventory, albeit weaker (about $20 \%$ of the landslides in continuously forested-covered areas). This is consistent with the reported drawbacks of such landslide inventories [26,27]. Unreflecting model interpretation might thus lead to the conclusion that forest areas are more susceptible for landslides than other LULC categories (i.e., contrasting the findings of $[4,5,13,73])$. We assume that the inventory bias results from the fact that landslide traces on agricultural land are quickly "tilled away" (Figure 1D), and that landslides affecting the built environment are removed during reconstruction, while in forests, they are preserved for an extended period of time (see Figure 12 in [28]).

For bias mitigation, we explored three approaches. Following the recommendations of Petschko et al. [27], (i) dropping the bias-describing predictor from modeling (i.e., LULC; GAM-Base) had only minor effects on the predictor-response relationships compared to the other models (excluding GAM-2015-Masked). We assume that confounding effects may explain these minor differences (e.g., slope angle: forest area more likely located on steeper slopes [26]). Besides, (ii) excluding inventory-biasing observations (i.e., continuously forestcovered areas; GAM-2015-Masked) led to substantial differences of predictor-response relationships for some variables (e.g., slope angle in both study areas, profile curvature in Paldau, lithology in Waidhofen, Figure 5), yet the OR of the LULC categories in reference to forest were similar to GAM-2015. However, since the relationships are in general agreement with other research results [73,74] (Figure 6), further research might help to evaluate and identify the "true" relationship. Moreover, reducing the models' training data may not always be suitable (e.g., sparse inventories), and might even decrease model performances $[77,78]$. (iii) Using LULC legacy information (i.e., biomass extraction, GAM1820 and GAM-1960), the predictor-response relationships matched GAM-Base except for the minor differences mentioned above, and we could reduce the bias of a higher landslide chance on forest area relative to other LULC categories. Additionally, we identified a tendency towards relatively lower OR in forests using long-term legacies. Albeit the landslide inventory bias still had an effect on the landslide models for all approaches, for studies based on airborne LiDAR-derived landslide inventories we recommend to exclude bias-describing predictors (e.g., LULC) in the first place, or to enrich the feature space with a bias-reducing information predictor (e.g., LULC legacies).

Moreover, when considering LULC as a predictor, it should be kept in mind that each study area has its unique legacy. The transferability assessment showed a poorer transferability of landslide models that were fit only in one study area (AUROC loss up to 0.14 , Figure 3). While the transformation functions of slope angle, plan curvature and the LULC legacy category forest matched between study areas, for other important variables they were partly (e.g., concave profile curvature) or even completely opposed (e.g., slope aspect, S-N and other LULC legacy categories; Figures A2 and A3). Moreover, landslide models using the combined data did not improve performances compared to both area-specific models. However, for event-based landslide modeling with especially sparse inventories, the opposite may be true (see Figure 4 in [73]).

Regarding the variable importance assessment, the results are in agreement with findings in other studies despite different landslide inventories: For Waidhofen, Steger et al. [74] also identified the slope angle as the most influential predictor, while present-day land cover ranked last. In the landslide model of Knevels et al. [73] fitted in southeast Styria (where Paldau is located), the present-day LULC (categorized into forest classes) and slope angle ranked second and third, respectively. We conjecture that the lower influence and different shape of the slope aspect relationship (Figure 5) could be due to effects such as pre- or post-failure HRDTM or the specific rainfall event in the study of [73]. 


\subsection{Study Data: Challenges and Requirements}

We encourage the use of long-term LULC legacy data in landslide studies. The presented LULC legacy predictor is not only a simple and comprehensible way to highlight historical LULC dynamics but may also support spatial planning in preventive disaster reduction regarding future LULC changes. With historical cartographic documents of several countries (e.g., Habsburg, Franciscan or Napoleonic cadastral map) [79] and information on long-term biomass extraction $[80,81]$ becoming increasingly available in a pre-processed form, there is a real opportunity to further explore LULC legacies in future studies.

For the creation of LULC legacy data, we used data sources of different spatial, temporal and thematic quality and resolution (Table 1). For the time cut of 1960, the available greyscale aerial photographs for the municipalities were nine years apart (Paldau 1953 and Waidhofen 1962). Thus, LULC changes in the context of the "economic miracle" (e.g., mechanized agriculture, urban growth and sprawl) beginning in 1955 may not yet be present in Paldau [82]. Also, the interpretation of the greyscale aerial photographs of low image quality was particularly challenging (especially grassland vs. cropland). Additionally, the thematic resolution of the data sources used for the biomass extraction (i.e., wood and agricultural yields) was very heterogeneous in terms of the aggregated spatial statistical reference unit (e.g., the data availability for wood yields was for time cut 1960 on a national scale and for 2015 on for federal states). Nevertheless, we suggest that the data still allows conclusions to be drawn about long-term trends $[43,45,81]$. We acknowledge that the digitization of LULC legacy data was a time-consuming process and historical imagery at an appropriate scale may not be available everywhere.

The landslide inventories were separately created for each study area by local experts. There is evidence that landslide inventories are not only incomplete to an unknown degree [24], but also that landslide inventories compiled by different experts may have positional mismatches up to $70 \%$ [23]. Therefore, in this study, consistent rules were agreed upon to ensure or at least strive for a homogeneous inventory quality (e.g., uniform digitization scale, order of digitization: first landslide scarp, then body, etc.). To overcome the drawbacks of the inventory (e.g., bias in forest areas) and to enhance the explanatory power of the LULC legacy variables in modeling landslides, we encourage to collect and analyze additional historical aerial photographs, orthophotos or satellite images in order to estimate landslide ages $[4,11,27]$.

\section{Conclusions and Outlook}

In this study, LULC and legacies of its change could successfully improve the explanation of landslide distribution as we identified the LULC variable as a meaningful predictor in landslide susceptibility modeling. Higher biomass extraction resulted in higher landslide susceptibility (excluding cropland in Paldau), explaining different risk levels in areas with the same present-day LULC. Furthermore, we could confirm that airborne LiDAR-derived inventories may be biased towards currently forested areas (e.g., high landslide density in Paldau with a FR of 2.5). Using long-term LULC legacy variables accounting for changes for almost 200 years, we could successfully reduce the effects of LULC-related inventory bias. However, without any information on the failure date or at least an approximated time slice, the additional landslides preserved in forest areas may still lead to an unknown bias in the model, and thus lead to potentially contradictory relationships between landslide occurrences and LULC legacies (e.g., OR $<0.33$ outside forest relative to forest areas in Paldau). Other bias-avoiding strategies such as removing inventory-biasing observation led to improved model performances, but also to different predictor-response relationships. Thus, the implementation and interpretation of LULC as a bias-describing predictor must be carefully considered. We highly encourage further research using event-based landslide inventories with known landslide ages or age ranges to avoid such biases. 
The construction of historical LULC datasets is relevant for future use both from methodological and empirical perspectives. Methodologically, the approach chosen here can be used in future analyses in cases where both geographic and statistical information on LULC are available and can be combined. Empirically, the dataset established may be used for future analyses of different issues related to long-term LULC change, in particular those related to sustainable LULC intensification (e.g., cultural landscape change [45]). With the publication of the historical LULC legacy dataset [49], we highly encourage future research with this data and a replication of the analysis, especially once a reliable event-based landslide inventory for the study areas is available.

Supplementary Materials: The following are available online at https: / www.mdpi.com/article / 10.3390/land10090954/s1: Landslide inventories and landslide susceptibility models of both study areas.

Author Contributions: Conceptualization, R.K., A.B. and H.P. (Helene Petschko); data curation, T.L., H.P. (Herwig Proske), G.H., R.K., C.P. and S.G. formal analysis, R.K.; funding acquisition, P.L., S.G. and H.P. (Helene Petschko); methodology, R.K., A.B. and H.P. (Helene Petschko); supervision, H.P. (Helene Petschko) and A.B.; writing—original draft, R.K.; writing—review \& editing, R.K., A.B., S.G., G.H., T.L., P.L., C.P., H.P. (Herwig Proske) and H.P. (Helene Petschko). All authors have read and agreed to the published version of the manuscript.

Funding: This research was conducted within the Integrating Land use Legacies in Landslide Risk Assessment to support Spatial Planning (ILLAS) project funded by the Austrian Climate Research Program (ACRP), grant number KR16AC0K13226. The contribution of S. Gingrich was also financially supported by the European Research Council (ERC-2017-StG 757995 HEFT). We acknowledge support by the German Research Foundation and the Open Access Publication Fund of the Thueringer Universitaets- und Landesbibliothek Jena Projekt-Nr. 433052568.

Institutional Review Board Statement: Not applicable.

Informed Consent Statement: Not applicable.

Data Availability Statement: The long-term spatially explicit information on land use 1830-19602015 are available at https://doi.org/10.5281/zenodo.4896571, accessed on 30 June 2021. The landslide inventories and susceptibility models of both study areas are accessible through the Supplementary Materials.

Acknowledgments: We are grateful to the GIS department of the Styrian government and the Provincial Government of Lower Austria for providing the high-resolution digital elevation models, orthophotos, and the datasets of hydrologic and hydropedologic characteristics. Furthermore, we thank the Geological Survey of Austria and the Styrian GIS department for providing the geological base maps.

Conflicts of Interest: The authors declare no conflict of interest. The funders had no role in the design of the study; in the collection, analyses, or interpretation of data; in the writing of the manuscript, or in the decision to publish the results. 


\section{Appendix A. Descriptive Summary of Input Data}

Table A1. Sources of land surface data.

\begin{tabular}{|c|c|c|}
\hline Study Area & Source Holder & Resolution \\
\hline \multicolumn{3}{|c|}{ airborne LiDAR-based high-resolution digital terrain model } \\
\hline Waidhofen & provincial government of Lower Austria & $1 \mathrm{~m} \times 1 \mathrm{~m}$, acquisition year: 2014 \\
\hline Paldau & GIS department of the Styrian government & $1 \mathrm{~m} \times 1 \mathrm{~m}$, acquisition year: 2009 \\
\hline \multicolumn{3}{|c|}{ hydrologic and hydropedologic parameters } \\
\hline $\begin{array}{l}\text { Waidhofen } \\
\text { Paldau }\end{array}$ & Austrian Research Centre for Forests & $\begin{array}{c}50 \mathrm{~m} \times 50 \mathrm{~m} \text {, year: } 2014 \\
100 \mathrm{~m} \times 100 \mathrm{~m} \text {, year } 2017\end{array}$ \\
\hline \multicolumn{3}{|c|}{ geological basemaps } \\
\hline Waidhofen & Geological Survey of Austria & $1: 50,000$ \\
\hline Paldau & GIS department of the Styrian government & $1: 50,000$ \\
\hline
\end{tabular}

Table A2. Overview of the classification and recording of land use classes according to time cut.

land Use/Land Cover Category

\section{Time Cut 1820 \\ LULC Types in the \\ Franciscan Cadastre}

\section{Time Cut 2015}

IACS, Orthophotos forest (including forest pasture)

grassland

cropland

settlement and other
Hardwood forests, Coniferous forests, Mixed

forests, Chestnut forests, Meadows with fruit

trees

\begin{tabular}{ccc}
\hline grassland & $\begin{array}{c}\text { Dry meadows, wet meadows, pastures, } \\
\text { community pastures, shrubs }\end{array}$ & $\begin{array}{c}\text { IACS agricultural parcel: Grassland, alpine } \\
\text { pastures, pasture }\end{array}$ \\
\hline cropland & $\begin{array}{c}\text { Orchards, vegetable gardens, vineyards, arable } \\
\text { land (with fruit trees, trees and vines) }\end{array}$ & IACS agricultural parcel: arable land \\
\hline settlement and other & $\begin{array}{c}\text { Marshes, lakes, ponds, rivers and streams, } \\
\text { wastelands and bare rocks, buildings (all } \\
\text { types), trails (all types) }\end{array}$ & $\begin{array}{c}\text { Remaining area, which includes, e.g., } \\
\text { buildings, impervious surfaces, water } \\
\text { bodies, excavation pits and quarries, urban } \\
\text { green, near-natural areas }\end{array}$ \\
\hline
\end{tabular}

* LULC types not listed here are not present in the study area; LULC classes of the 1960 time cut were digitized in aerial photographs, modified from Knevels et al. [45].

Table A3. Summary of the landslide inventory data.

\begin{tabular}{|c|c|c|c|c|c|c|c|}
\hline & & \multicolumn{3}{|c|}{ Waidhofen } & \multicolumn{3}{|c|}{ Paldau } \\
\hline \multirow[t]{4}{*}{ Number } & landslides & \multicolumn{3}{|c|}{621} & \multicolumn{3}{|c|}{418} \\
\hline & scarps & \multicolumn{3}{|c|}{829} & \multicolumn{3}{|c|}{469} \\
\hline & bodies & \multicolumn{3}{|c|}{663} & \multicolumn{3}{|c|}{348} \\
\hline & samples & \multicolumn{3}{|c|}{974} & \multicolumn{3}{|c|}{559} \\
\hline \multirow[t]{2}{*}{ Total Area $\left[\mathrm{m}^{2}\right](\%)$} & landslides & \multicolumn{3}{|c|}{$6,976,638(5.31)$} & \multicolumn{3}{|c|}{$1,621,250(4.14)$} \\
\hline & & $\min$ & mean & $\max$ & $\min$ & mean & $\max$ \\
\hline \multirow[t]{3}{*}{ Area $\left[\mathrm{m}^{2}\right]$} & landslides & 113 & 11,235 & $1,163,088$ & 30 & 3879 & 206,842 \\
\hline & scarps & 2 & 517 & 79,640 & 12 & 140 & 1518 \\
\hline & bodies & 52 & 9876 & $1,083,448$ & 24 & 3949 & 206,842 \\
\hline \multirow[t]{3}{*}{ Perimeter [m] } & landslides & 44 & 451 & 7250 & 26 & 163 & 1821 \\
\hline & scarps & 7 & 101 & 3013 & 18 & 71 & 373 \\
\hline & bodies & 29 & 297 & 4548 & 28 & 168 & 1821 \\
\hline
\end{tabular}



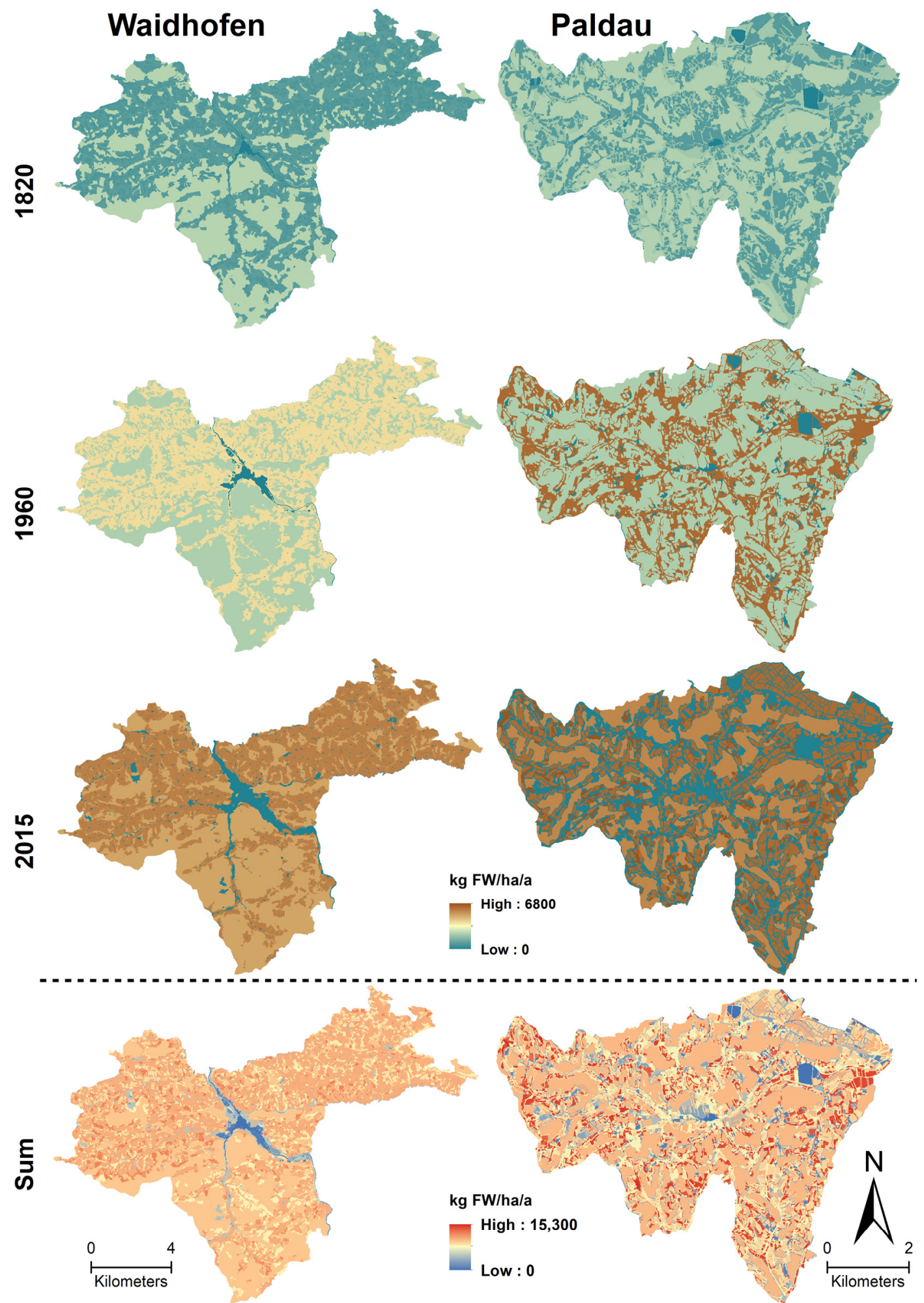

Figure A1. Biomass extraction $[\mathrm{kg} \mathrm{FW} / \mathrm{ha} / \mathrm{a}]$ as an indicator of historical land use intensity of study areas. 


\section{Appendix B. Summary of Model Assessment Results}

Table A4. Results of the model assessments within the study area with $\mathrm{SpCV}$, and assessment of model transferability between both areas.

\begin{tabular}{cccccc}
\hline Model & $\tilde{\boldsymbol{x}}$ & Min & Max & IQR & Transfer \\
\hline GAM-Base & 0.79 & A: Waidhofen & & & \\
GAM-2015 & 0.79 & 0.7 & 0.91 & 0.14 & 0.65 \\
GAM-2015-Masked & 0.8 & 0.69 & 0.91 & 0.14 & 0.64 \\
GAM-1960 & 0.79 & 0.7 & 0.91 & 0.13 & 0.69 \\
GAM-1820 & 0.78 & 0.7 & 0.91 & 0.14 & 0.65 \\
& & B: Paldau & 0.91 & 0.14 & 0.65 \\
GAM-Base & 0.88 & 0.83 & 0.93 & 0.03 & 0.83 \\
GAM-2015 & 0.89 & 0.85 & 0.94 & 0.06 & 0.8 \\
GAM-2015-Masked & 0.93 & 0.88 & 0.98 & 0.04 & 0.85 \\
GAM-1960 & 0.89 & 0.85 & 0.94 & 0.06 & 0.78 \\
GAM-1820 & 0.89 & 0.85 & 0.94 & 0.06 & 0.79 \\
GAM-Base & 0.81 & C: Combined & & & \\
GAM-2015 & 0.81 & 0.74 & 0.91 & 0.07 & \\
GAM-2015-Masked & 0.84 & 0.75 & 0.91 & 0.07 & \\
GAM-1960 & 0.82 & 0.74 & 0.93 & 0.07 & \\
GAM-1820 & 0.81 & 0.74 & 0.91 & 0.07 & \\
\hline
\end{tabular}

AUROC Statistic: median ( $\widetilde{x})$, minimum (Min), maximum (Max), interquartile range (IQR), transferability estimate (Transfer).

Table A5. Wilcoxon signed-rank tests for AUROC performance differences within each study area estimated with SpCV.

\begin{tabular}{cccccc}
\hline Model & mAUROC & $\mathbf{N}^{*}$ & $\mathbf{Z}$ & $p$-Values & $r$ \\
\hline GAM-2015 & 0.79 & A: Waidhofen & & & \\
<GAM-1820 & 0.78 & 36 & 2.7 & 0.01 & 0.45 \\
=GAM-Base & 0.79 & 35 & 0.93 & 0.18 & 0.16 \\
<GAM-1960 & 0.79 & 36 & 4.24 & $<0.001$ & 0.72 \\
<GAM-2015-Masked & 0.80 & 36 & 2.24 & 0.02 & 0.37 \\
& & B: Paldau & & & \\
GAM-Base & 0.88 & & & & \\
<GAM-1960 & 0.89 & 66 & 5.01 & $<0.001$ & 0.62 \\
<GAM-1820 & 0.89 & 66 & 4.35 & $<0.001$ & 0.54 \\
=GAM-2015 & 0.89 & 66 & 1.54 & 0.06 & 0.19 \\
< GAM-2015-Masked & 0.93 & 66 & 7.03 & $<0.001$ & 0.87 \\
\hline
\end{tabular}

mAUROC: median AUROC of SpCV; N: Number of observations per group; ${ }^{*}$ tied observations were removed; Z: Z score;alternative hypothesis: greater, $\alpha=0.05$; <: Differences significantly greater from previous model, =: No significant difference to the previous model. 
Table A6. Variable importance measured as mean decrease in deviance explained (\%), rank of variable in parentheses.

\begin{tabular}{|c|c|c|c|c|c|c|}
\hline Variable & $\begin{array}{l}\text { Study } \\
\text { Area }\end{array}$ & GAM-Base & GAM-2015 & $\begin{array}{l}\text { GAM-2015- } \\
\text { Masked }\end{array}$ & GAM-1960 & GAM-1820 \\
\hline \multirow{3}{*}{$\begin{array}{c}\text { land surface variable } \\
\text { convergence index, } 100 \mathrm{~m}\end{array}$} & & & & & & \\
\hline & Wh & $1.23(5)$ & $1.27(5)$ & $1.3(6)$ & $1.15(5)$ & $1.17(5)$ \\
\hline & $\mathrm{P}$ & $0.91(7)$ & $0.97(8)$ & $0.71(11)$ & $0.96(8)$ & $0.98(7)$ \\
\hline \multirow{2}{*}{ convergence index, 500 m } & Wh & $0.87(8)$ & $0.86(9)$ & $0.99(9)$ & $0.83(10)$ & $0.86(9)$ \\
\hline & $\mathrm{P}$ & $0.93(6)$ & $1.16(6)$ & $3.25(4)$ & $1.2(6)$ & $1.18(6)$ \\
\hline \multirow{2}{*}{ curvature, plan } & Wh & $2.09(3)$ & $2.1(3)$ & $2.83(3)$ & $2.17(3)$ & $2.17(3)$ \\
\hline & $\mathrm{P}$ & $2.38(4)$ & $1.43(5)$ & $0.84(10)$ & $1.46(5)$ & $1.49(5)$ \\
\hline \multirow{2}{*}{ curvature, profile } & Wh & $1.45(4)$ & $1.58(4)$ & $1.78(4)$ & $1.65(4)$ & $1.57(4)$ \\
\hline & $\mathrm{P}$ & $3.32(3)$ & $3.2(3)$ & $6.37(1)$ & $3.08(3)$ & $3.05(3)$ \\
\hline \multirow[b]{2}{*}{ flow accumulation } & Wh & $0.42(13)$ & $0.43(12)$ & $0.48(14)$ & $0.5(13)$ & $0.46(12)$ \\
\hline & $\mathrm{P}$ & $0.07(15)$ & $0.2(16)$ & $0.46(13)$ & $0.22(16)$ & $0.21(16)$ \\
\hline \multirow{2}{*}{ normalized height } & Wh & $0.02(15)$ & $0.02(16)$ & $0.05(16)$ & $0.04(16)$ & $0.03(16)$ \\
\hline & $\mathrm{P}$ & $0.95(5)$ & $0.95(9)$ & $3.15(5)$ & $0.93(9)$ & $0.93(9)$ \\
\hline \multirow{2}{*}{ slope angle } & Wh & $8.01(1)$ & $7.7(1)$ & $8.63(1)$ & $7.45(1)$ & $7.61(1)$ \\
\hline & $\mathrm{P}$ & $7.68(1)$ & $4.38(1)$ & $4.62(2)$ & $4.77(1)$ & $4.64(1)$ \\
\hline \multirow{2}{*}{ slope angle, catchment area } & Wh & $1.11(7)$ & $1.15(6)$ & $1.1(8)$ & $1.07(7)$ & $1.15(6)$ \\
\hline & $\mathrm{P}$ & $0.55(11)$ & $0.47(12)$ & $0.2(15)$ & $0.44(12)$ & $0.43(12)$ \\
\hline \multirow{2}{*}{ slope aspect, S-N } & Wh & $1.12(6)$ & $1.07(7)$ & $1.11(7)$ & $1.06(8)$ & $1.12(7)$ \\
\hline & $\mathrm{P}$ & $3.94(2)$ & $2.3(4)$ & $1.25(8)$ & $2.36(4)$ & $2.33(4)$ \\
\hline \multirow{2}{*}{ slope aspect, W-E } & Wh & $0.61(11)$ & $0.58(11)$ & $0.84(10)$ & $0.52(12)$ & $0.56(11)$ \\
\hline & $\mathrm{P}$ & $0.32(13)$ & $0.29(14)$ & $1.68(6)$ & $0.27(15)$ & $0.27(15)$ \\
\hline \multirow{2}{*}{ TPI } & Wh & $0.86(9)$ & $0.89(8)$ & $1.64(5)$ & $0.89(9)$ & $0.91(8)$ \\
\hline & $\mathrm{P}$ & $0.7(9)$ & $0.84(11)$ & $0.14(16)$ & $0.84(11)$ & $0.84(11)$ \\
\hline \multirow{2}{*}{ SWI } & Wh & $0.66(10)$ & $0.66(10)$ & $0.39(15)$ & $0.68(11)$ & $0.67(10)$ \\
\hline & $\mathrm{P}$ & $0.66(10)$ & $0.39(13)$ & $0.95(9)$ & $0.35(13)$ & $0.35(13)$ \\
\hline \multicolumn{7}{|l|}{ soil } \\
\hline \multirow{2}{*}{ total pore volume } & Wh & $0.35(14)$ & $0.31(14)$ & $0.51(13)$ & $0.29(15)$ & $0.31(15)$ \\
\hline & $\mathrm{P}$ & $0.47(12)$ & $0.86(10)$ & $0.68(12)$ & $0.87(10)$ & $0.87(10)$ \\
\hline \multirow{2}{*}{ hydraulic conductivity } & Wh & $0.44(12)$ & $0.41(13)$ & $0.62(11)$ & $0.35(14)$ & $0.38(14)$ \\
\hline & $\mathrm{P}$ & $0.9(8)$ & $0.98(7)$ & $1.3(7)$ & $0.98(7)$ & $0.97(8)$ \\
\hline lithology & & & & & & \\
\hline \multirow{2}{*}{$\begin{array}{l}\text { lithology } \\
\text { lithology/geology }\end{array}$} & Wh & $6.38(2)$ & $6.37(2)$ & $3.72(2)$ & $6.37(2)$ & $6.34(2)$ \\
\hline & $\mathrm{P}$ & $0.25(14)$ & $0.27(15)$ & $0.39(14)$ & $0.27(14)$ & $0.28(14)$ \\
\hline \multicolumn{7}{|l|}{ land use/land cover legacy } \\
\hline \multirow{2}{*}{ LULC 2015} & Wh & & $0.26(15)$ & $0.6(12)$ & & \\
\hline & $\mathrm{P}$ & & $3.64(2)$ & $3.92(3)$ & & \\
\hline \multirow{2}{*}{ biomass extraction, 1960 * } & Wh & & & & $1.07(6)$ & \\
\hline & $\mathrm{P}$ & & & & $3.81(2)$ & \\
\hline \multirow{2}{*}{ biomass extraction, 1820 * } & Wh & & & & & $0.43(13)$ \\
\hline & $\mathrm{P}$ & & & & & $3.85(2)$ \\
\hline
\end{tabular}

${ }^{*}$ Biomass extraction in interaction with LULC 2015; Wh: Waidhofen, P: Paldau. 

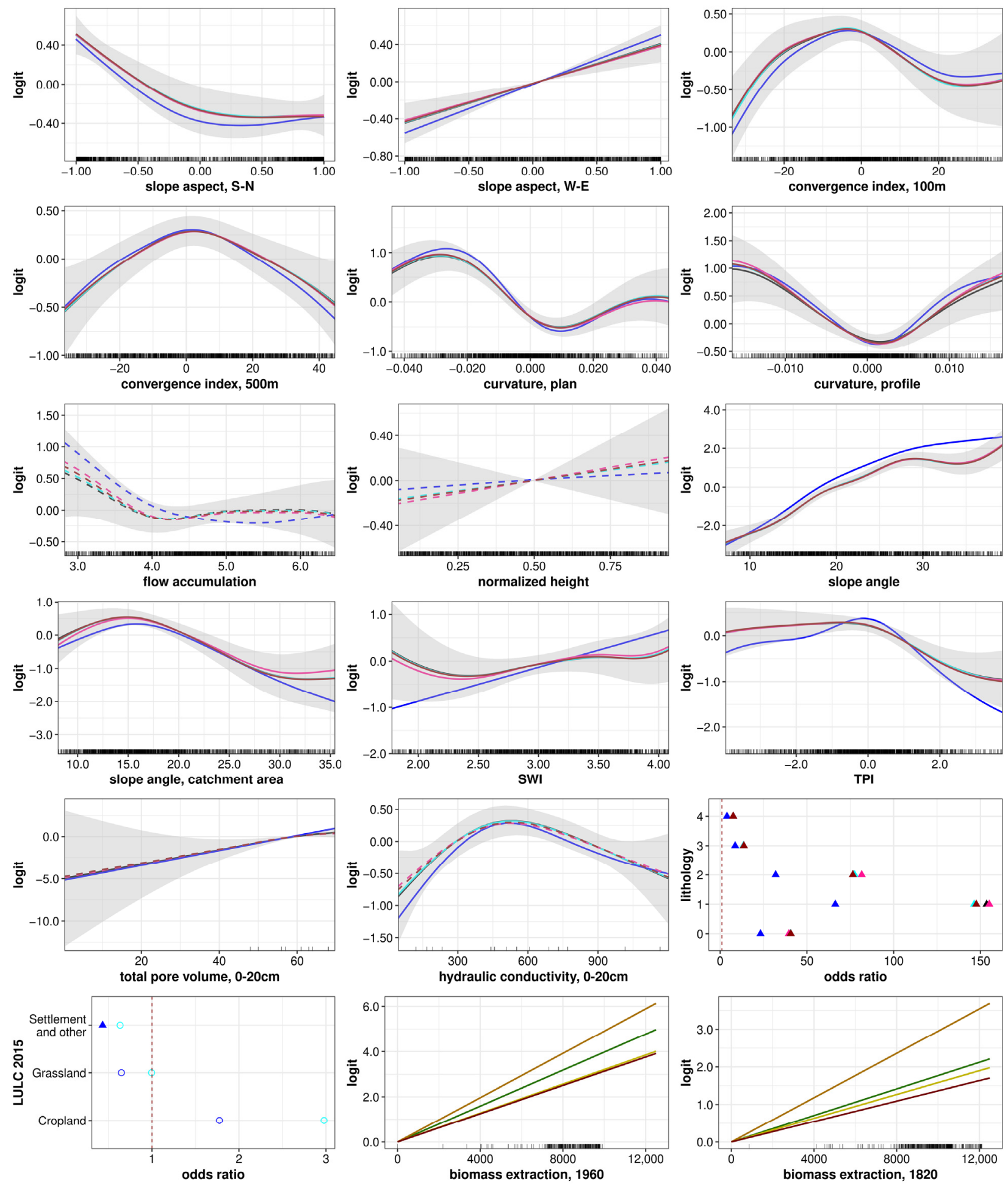

Model

Predictor

Land use/land cover

- GAM-Base - GAM-2015 — GAM-2015-Masked - GAM-1960 - GAM-1820

- not significant - significant — Forest - Grassland

- GAM-Base - GAM-2015 - GAM-2015-Masked - GAM-1960 • GAM-1820

$\circ$ not significant $\Delta$ significant - Cropland - Settlement and other

Figure A2. Predictor-response relationships of landslide models in Waidhofen. Grey: 95\% Bayesian credible interval of GAM-Base. Reference level of LULC 2015: 'Forest'; Lithological units: Reference: 'Upper Austroalpine limestone', 0: talus and glacial deposits, 1: Inneralpine Neogene, 2: Klippen zone, 3: flysch zone, 4: Upper Austroalpine marls. Note: the y axes are plot-dependent, and the $x$ axes of non-parametric transformation functions are limited to the 5th to 95th percentile range. 

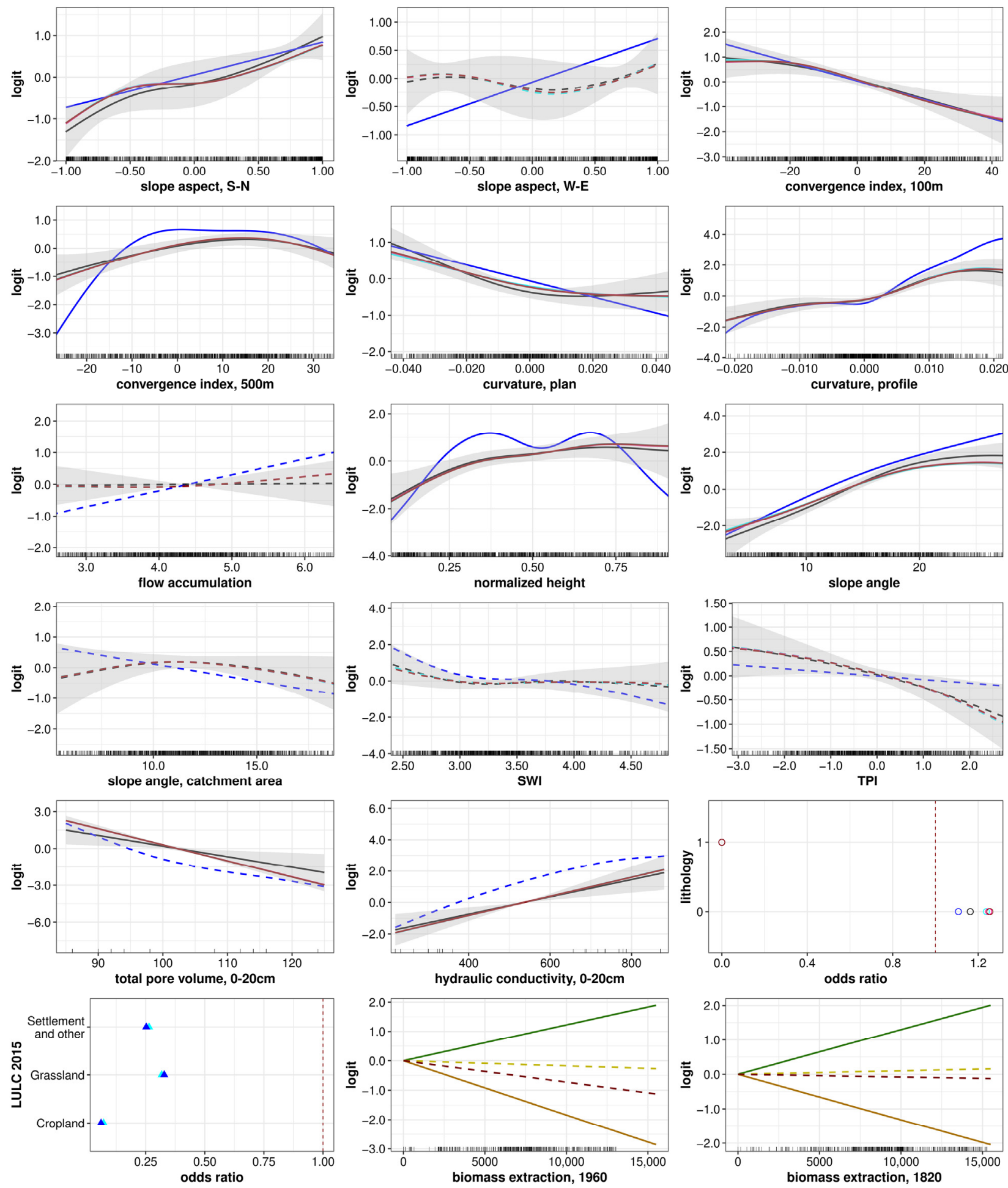

Model

Predictor

Land use/land cover

— GAM-Base - GAM-2015 — GAM-2015-Masked — GAM-1960 — GAM-1820

- not significant - significant — Forest - Grassland

- GAM-Base - GAM-2015 • GAM-2015-Masked • GAM-1960 • GAM-1820

○ not significant $\Delta$ significant - Cropland - Settlement and other

Figure A3. Predictor-response relationships of landslide models in Paldau. Grey: 95\% Bayesian credible interval of GAMBase. Reference level of LULC 2015: 'Forest'; Lithological units: Reference: 'Neogene formations with coarse-grained layers', 0: 'Neogene formations dominated by fine-grained sediments', 1: 'pre-Würmian Pleistocene formations'. Note: the y axes are plot-dependent, and the $x$ axes of non-parametric transformation functions are limited to the 5th to 95th percentile range. 


\section{References}

1. Crozier, M.J.; Glade, T. Landslide Hazard and Risk: Issues, Concepts and Approach. In Landslide Hazard and Risk; Glade, T., Anderson, M., Crozier, M.J., Eds.; John Wiley \& Sons: Chichester, UK, 2005; pp. 1-40.

2. Gariano, S.L.; Guzzetti, F. Landslides in a changing climate. Earth-Sci. Rev. 2016, 162, 227-252. [CrossRef]

3. Schweigl, J.; Hervás, J. Landslide Mapping in Austria; European Commission, Joint Research Centre: Luxembourg; Ispra, Italy, 2009. [CrossRef]

4. Reichenbach, P.; Busca, C.; Mondini, A.C.; Rossi, M. The Influence of Land Use Change on Landslide Susceptibility Zonation: The Briga Catchment Test Site (Messina, Italy). Environ. Manag. 2014, 54, 1372-1384. [CrossRef] [PubMed]

5. Papathoma-Köhle, M.; Glade, T. The role of vegetation cover change for landslide hazard and risk. In The Role of Ecosystems in Disaster Risk Reduction; UNU-Press: Tokyo, Japan, 2013; pp. 293-320.

6. Brenning, A.; Schwinn, M.; Ruiz-Páez, A.P.; Muenchow, J. Landslide susceptibility near highways is increased by 1 order of magnitude in the Andes of southern Ecuador, Loja province. Nat. Hazards Earth Syst. Sci. 2015, 15, 45-57. [CrossRef]

7. Goetz, J.; Guthrie, R.H.; Brenning, A. Forest harvesting is associated with increased landslide activity during an extreme rainstorm on Vancouver Island, Canada. Nat. Hazards Earth Syst. Sci. 2015, 15, 1311-1330. [CrossRef]

8. van Westen, C.J.; Castellanos, E.; Kuriakose, S.L. Spatial data for landslide susceptibility, hazard, and vulnerability assessment: An overview. Eng. Geol. 2008, 102, 112-131. [CrossRef]

9. Beguería, S. Changes in land cover and shallow landslide activity: A case study in the Spanish Pyrenees. Geomorphology 2006, 74, 196-206. [CrossRef]

10. Gariano, S.L.; Petrucci, O.; Rianna, G.; Santini, M.; Guzzetti, F. Impacts of past and future land changes on landslides in southern Italy. Reg. Environ. Chang. 2018, 18, 437-449. [CrossRef]

11. Persichillo, M.G.; Bordoni, M.; Meisina, C. The role of land use changes in the distribution of shallow landslides. Sci. Total Environ. 2017, 574, 924-937. [CrossRef] [PubMed]

12. Pisano, L.; Zumpano, V.; Malek, Ž.; Rosskopf, C.M.; Parise, M. Variations in the susceptibility to landslides, as a consequence of land cover changes: A look to the past, and another towards the future. Sci. Total Environ. 2017, 601-602, 1147-1159. [CrossRef]

13. Lopez-Saez, J.; Corona, C.; Eckert, N.; Stoffel, M.; Bourrier, F.; Berger, F. Impacts of land-use and land-cover changes on rockfall propagation: Insights from the Grenoble conurbation. Sci. Total Environ. 2016, 547, 345-355. [CrossRef]

14. Cuddington, K. Legacy Effects: The Persistent Impact of Ecological Interactions. Biol. Theory 2011, 6, 203-210. [CrossRef]

15. Foster, D.; Swanson, F.; Aber, J.; Burke, I.; Brokaw, N.; Tilman, D.; Knapp, A. The Importance of Land-Use Legacies to Ecology and Conservation. BioScience 2003, 53, 77-88. [CrossRef]

16. Munteanu, C.; Kuemmerle, T.; Keuler, N.S.; Müller, D.; Balázs, P.; Dobosz, M.; Griffiths, P.; Halada, L.; Kaim, D.; Király, G.; et al. Legacies of 19th century land use shape contemporary forest cover. Glob. Environ. Chang. 2015, 34, 83-94. [CrossRef]

17. Kuussaari, M.; Bommarco, R.; Heikkinen, R.K.; Helm, A.; Krauss, J.; Lindborg, R.; Öckinger, E.; Pärtel, M.; Pino, J.; Rodà, F.; et al. Extinction debt: A challenge for biodiversity conservation. Trends Ecol. Evol. 2009, 24, 564-571. [CrossRef]

18. Perring, M.P.; Frenne, P.D.; Baeten, L.; Maes, S.L.; Depauw, L.; Blondeel, H.; Carón, M.M.; Verheyen, K. Global environmental change effects on ecosystems: The importance of land-use legacies. Glob. Chang. Biol. 2016, 22, 1361-1371. [CrossRef]

19. Sonny Digital LiDAR-Terrain Models of Austria (last change 02 March 2021 16:01:16) 2016. Available online: https://data. opendataportal.at/dataset/dtm-austria (accessed on 30 June 2021).

20. Haugerud, R.; Harding, D.; Johnson, S.; Harless, J.; Weaver, C.; Sherrod, B. High-Resolution Lidar Topography of the Puget Lowland, Washington -A Bonanza for Earth Science. GSA Today 2003, 13. [CrossRef]

21. Petschko, H.; Bell, R.; Glade, T. Effectiveness of visually analyzing LiDAR DTM derivatives for earth and debris slide inventory mapping for statistical susceptibility modeling. Landslides 2016, 13, 857-872. [CrossRef]

22. Schulz, W.H. Landslides mapped using LIDAR imagery, Seattle, Washington. US Geol. Surv. Open-File Rep. 2004, 1396. [CrossRef]

23. Eeckhaut, M.V.D.; Poesen, J.; Verstraeten, G.; Vanacker, V.; Nyssen, J.; Moeyersons, J.; Beek, L.P.H.v.; Vandekerckhove, L. Use of LIDAR-derived images for mapping old landslides under forest. Earth Surf. Process. Landf. 2007, 32, 754-769. [CrossRef]

24. Malamud, B.D.; Turcotte, D.L.; Guzzetti, F.; Reichenbach, P. Landslide inventories and their statistical properties. Earth Surf. Process. Landf. 2004, 29, 687-711. [CrossRef]

25. Stanley, T.A.; Kirschbaum, D.B. Effects of inventory bias on landslide susceptibility calculations. In Proceedings of the Landslides: Putting Experience, Knowledge and Emerging Technologies into Practice; Association of Environmental \& Engineering Geologists (AEG), Roanoke, VA, USA, 4-8 June 2017; pp. 794-806.

26. Steger, S.; Brenning, A.; Bell, R.; Glade, T. The influence of systematically incomplete shallow landslide inventories on statistical susceptibility models and suggestions for improvements. Landslides 2017, 14, 1767-1781. [CrossRef]

27. Petschko, H.; Bell, R.; Glade, T. Relative Age Estimation at Landslide Mapping on LiDAR Derivatives: Revealing the Applicability of Land Cover Data in Statistical Susceptibility Modelling. In Landslide Science for a Safer Geoenvironment; Springer Nature: Cham, Switzerland, 2014; pp. 337-343.

28. Bell, R.; Petschko, H.; Röhrs, M.; Dix, A. Assessment of landslide age, landslide persistence and human impact using airborne laser scanning digital terrain models. Geogr. Ann. Ser. A Phys. Geogr. 2012, 94, 135-156. [CrossRef]

29. van Westen, C.J.; van Asch, T.W.J.; Soeters, R. Landslide hazard and risk zonation-why is it still so difficult? Bull. Eng. Geol. Environ. 2006, 65, 167-184. [CrossRef] 
30. STATISTIK AUSTRIA Ein Blick auf die Gemeinde Waidhofen an der Ybbs (30301). Österreich Besser Verstehen. Bevölkerungsentwicklung 1869-2019 [A Look at the Municipality of Waidhofen an der Ybbs (30301). Understanding Austria Better. Population Development 1869-2019] 2011. Available online: https:/ / www.statistik.at/blickgem/G0201/g30301.pdf (accessed on 30 June 2021).

31. Wessely, G. Geologie der Österreichischen Bundesländer-Niederösterreich [Geology of the Austrian Federal Provinces-Lower Austria]; Verlag der Geologischen Bundesanstalt: Wien, Österreich, 2006.

32. Gross, M. Beitrag zur Lithostratigraphie des Oststeirischen Beckens (Neogen/Pannonium; Österreich). In Stratigraphia Austriaca; Piller, W.E., Ed.; Schriftenreihe der Erdwissenschaftlichen Kommissionen/Österreichische Akademie der Wissenschaften; Österreichische Akademie der Wissenschaften: Wien, Austria, 2003; pp. 11-62.

33. STATISTIK AUSTRIA Ein Blick auf die Gemeinde Paldau (62384). Österreich Besser Verstehen. Bevölkerungsentwicklung 1869 -2019 [A Look at the Municipality of Paldau (62384). Understanding Austria Better. Population Development 1869-2019] 2011. Available online: https:/ / www.statistik.at/blickgem/G0201/g62384.pdf (accessed on 30 June 2021).

34. Bell, R.; Glade, T.; Granica, K.; Heiss, G.; Leopold, P.; Petschko, H.; Pomaroli, G.; Proske, H.; Schweigl, J. Landslide Susceptibility Maps for Spatial Planning in Lower Austria. In Landslide Science and Practice. Volume 1: Landslide Inventory and Susceptibility and Hazard Zoning; Margottini, C., Canuti, P., Sassa, K., Eds.; Springer: Berlin/Heidelberg, Germany, 2013; pp. 467-472.

35. Proske, H.; Bauer, C. Methodik zur Erstellung einer Gefahrenhinweiskarte für Rutschungen in der Steiermark [Methodology of the generation of an indicative hazard map for landslides in Styria]. Torrent Avalanche Landslide Rock Fall 2015, 175, 84-95.

36. Schwenk, H.; Spendlingwimmer, R.; Salzer, F. Massenbewegungen in Niederösterreich 1953-1990 [Mass Movements in Lower Austria 1953-1990]. Jahrb. Der Geol. Bundesanst. 1992, 132, 597-660.

37. Hornich, R.; Adelwöhrer, R. Landslides in Styria in 2009. Geomech. Tunn. 2010, 3, 455-461. [CrossRef]

38. Lemenkova, P.; Glade, T.; Promper, C. Economic Assessment of Landslide Risk for the Waidhofen a.d. Ybbs Region, Alpine Foreland, Lower Austria. Protecting Society through Improved Understanding. In Proceedings of the 11th International Symposium on Landslides and the 2nd NorthAmerican Symposium on Landslides and Engineered Slopes, Banff, AB, Canada, 2-8 June 2012; pp. 279-285. [CrossRef]

39. Eder, A.; Sotier, B.; Klebinder, K.; Sturmlechner, R.; Dorner, J.; Markat, G.; Schmid, G.; Strauss, P. Hydrologische Bodenkenndaten der Böden Niederösterreichs (HydroBodNÖ) [Data on Hydrological Soil Characteristics of Soils in Lower Austria]; Bundesamt für Wasserwirtschaft, Institut für Kulturtechnik und Bodenwasserhaushalt; Bundesforschungszentrum für Wald, Institut für Naturgefahren: Innsbruck, Austria, 2011.

40. Klebinder, K.; Sotier, B.; Lechner, V.; Strauss, P. Hydrologische und Hydropedologische Kenndaten. Raabgebiet und Region. Südoststeiermark [Hydrologic and Hydropedologic Characteristics. Region. of Raab and Southeast. Styria]; Bundesforschungszentrum für Wald, Bundesamt für Wasserwirtschaft: Innsbruck, Austria, 2017; p. 30. Available online: https:/ /wegenernet.org/downloads/ Klebinder-etal_HydroBod-SOStmk-Projbericht_Jul2017.pdf (accessed on 30 June 2021).

41. Bender, O. Analyse der Kulturlandschaftsentwicklung der Nördlichen Fränkischen Alb Anhand Eines Katasterbasierten Geoinformationssystems [Analysis of the Cultural Landscape Change of the Northern Franconian Alb Using a Cadastre-Based Geoinformation System]; Forschungen zur Deutschen Landeskunde; Deutsche Akademie für Landeskunde: Leipzig, Germany, 2007.

42. Sandgruber, R. Österreichische Agrarstatistik 1750-1918; Hoffmann, A., Matis, H., Eds.; Wirtschafts- und Sozialstatistik ÖsterreichUngarns; Verlag für Geschichte und Politik: Wien, Austria, 1978.

43. Gingrich, S.; Erb, K.-H.; Krausmann, F.; Gaube, V.; Haberl, H. Long-term dynamics of terrestrial carbon stocks in Austria: A comprehensive assessment of the time period from 1830 to 2000. Reg. Environ. Chang. 2007, 7, 37-47. [CrossRef]

44. Weiss, P.; Schieler, K.; Schadauer, K.; Englisch, M. Die Kohlenstoffbilanz des Österreichischen Waldes und Betrachtungen Zum Kyoto-Protokoll; Monographien; Umweltbundesamt: Wien, Austria, 2000.

45. Knevels, R.; Brenning, A.; Gingrich, S.; Gruber, E.; Lechner, T.; Leopold, P.; Petschko, H.; Plutzar, C. Kulturlandschaft im Wandel: Ein indikatorenbasierter Rückblick bis in das 19. Jahrhundert. Fallstudie anhand der Gemeinden Waidhofen/Ybbs und Paldau [Cultural Landscape Change: An Indicator-Based Retrospect into the 19th Century. Case Study of the Municipalities Waidhofen/Ybbs and Paldau]. Mitt. Der Osterreichischen Geogr. Ges. 2021, 162, 255-285. [CrossRef]

46. Erb, K.-H.; Haberl, H.; Jepsen, M.R.; Kuemmerle, T.; Lindner, M.; Müller, D.; Verburg, P.H.; Reenberg, A. A conceptual framework for analysing and measuring land-use intensity. Curr. Opin. Environ. Sustain. 2013, 5, 464-470. [CrossRef]

47. Mayer, A.; Haas, W.; Wiedenhofer, D. How Countries' Resource Use History Matters for Human Well-being-An Investigation of Global Patterns in Cumulative Material Flows from 1950 to 2010. Ecol. Econ. 2017, 134, 1-10. [CrossRef]

48. Matthews, H.D.; Zickfeld, K.; Knutti, R.; Allen, M.R. Focus on cumulative emissions, global carbon budgets and the implications for climate mitigation targets. Environ. Res. Lett. 2018, 13, 010201. [CrossRef]

49. Lechner, T.; Plutzar, C.; Knevels, R.; Gingrich, S. Long-Term Spatially Explicit Information on Land Use 1830-1960-2015: Case Study of the Municipalities Waidhofen/Ybbs and Paldau, Austria [Data set] 2021. 1.0.0. Available online: https://doi.org/10.528 1/zenodo.4896571 (accessed on 30 June 2021).

50. Cruden, D.M.; Varnes, D.J. Landslide Types and Processes. In Landslides Investigation and Mitigation. Transportation Research Board, US National Research Council; Turner, A.K., Schuster, R.L., Eds.; Special Report 247; U.S. National Academy of Sciences: Washington, DC, USA, 1996; pp. 36-75.

51. Hussin, H.Y.; Zumpano, V.; Reichenbach, P.; Sterlacchini, S.; Micu, M.; van Westen, C.; Bălteanu, D. Different landslide sampling strategies in a grid-based bi-variate statistical susceptibility model. Geomorphology 2016, 253, 508-523. [CrossRef] 
52. Steger, S.; Glade, T. The Challenge of "Trivial Areas" in Statistical Landslide Susceptibility Modelling. In Proceedings of the Advancing Culture of Living with Landslides, Ljubljana, Slovenia, 29 May-2 June 2017; Mikos, M., Tiwari, B., Yin, Y., Sassa, K., Eds.; Springer International Publishing: Cham, Switzerland, 2017; pp. 803-808. [CrossRef]

53. Hastie, T.; Tibshirani, R. Generalized Additive Models. Statist. Sci. 1986, 1, 297-310. [CrossRef]

54. Wood, S.N. Generalized Additive Models: An Introduction with R, 2nd ed.; Chapman and Hall/CRC: Boca Raton, FL, USA, 2017.

55. Brenning, A. Improved spatial analysis and prediction of landslide susceptibility: Practical recommendations. In Proceedings of the Landslides and Engineered Slopes: Protecting Society through Improved Understanding; Eberhardt, E., Froese, C., Turner, A.K., Leroueil, S., Eds.; CRC Press /Balkema: Banff, Canada, 2012; Volume 1, pp. 789-794.

56. R Core Team. R: A Language and Environment for Statistical Computing, R version 3.5.2.; R Foundation for Statistical Computing: Vienna, Austria, 2018. Available online: https:/ / www.R-project.org/ (accessed on 30 June 2021).

57. Bischl, B.; Lang, M.; Kotthoff, L.; Schiffner, J.; Richter, J.; Studerus, E.; Casalicchio, G.; Jones, Z.M. mlr: Machine Learning in R. J. Mach. Learn. Res. 2016, 17, 1-5.

58. Conrad, O.; Bechtel, B.; Dietrich, H.; Fischer, E.; Gerlitz, L.; Wehberg, J.; Wichmann, V.; Böhner, J. System for Automated Geoscientific Analyses (SAGA) v. 2.1.4. Geosci. Model. Dev. 2015, 8, 1991-2007. [CrossRef]

59. Brenning, A.; Bangs, D.; Becker, M. RSAGA: SAGA Geoprocessing and Terrain Analysis; 2018. R Package Version 1.3.0. Available online: https: / /CRAN.R-project.org/package=RSAGA (accessed on 30 June 2021).

60. Tarboton, D.G.; Dash, P.; Sazib, N. TauDEM 5.3: Guide to using the TauDEM command line functions 2015; Utah State University: Logan, UT, USA, 2015. Available online: http:/ / hydrology.usu.edu/taudem/taudem5/TauDEM53CommandLineGuide.pdf (accessed on 30 June 2021).

61. Koethe, R.; Lehmeier, F. SARA—System Zur Automatischen Relief-Analyse. User Manual, 2nd ed.; Department of Geography, University of Göttingen: Göttingen, Germany, 1996.

62. Zevenbergen, L.W.; Thorne, C.R. Quantitative Analysis of Land Surface Topography. Earth Surf. Process. Landf. 1987, 12, 47-56. [CrossRef]

63. Tarboton, D.G. A new method for the determination of flow directions and upslope areas in grid digital elevation models. Water Resour. Res. 1997, 33, 309-319. [CrossRef]

64. Dietrich, H.; Böhner, J. Cold Air Production and Flow in a Low Mountain Range Landscape in Hessia. In SAGA-Seconds Out; Böhner, J., Blaschke, T., Montanarella, L., Eds.; Hamburger Beiträge zur Physischen Geographie und Landschaftsökologie; Universität Hamburg, Institut für Geographie: Hamburg, Germany, 2008; Volume 19, pp. 37-48.

65. Böhner, J.; Selige, T. Spatial Prediction of Soil Attributes Using Terrain Analysis and Climate Regionalisation. Göttinger Geogr. Abh. 2006, 115, 13-27.

66. Brenning, A.; Trombotto, D. Logistic regression modeling of rock glacier and glacier distribution: Topographic and climatic controls in the semi-arid Andes. Geomorphology 2006, 81, 141-154. [CrossRef]

67. Guisan, A.; Weiss, S.B.; Weiss, A.D. GLM versus CCA spatial modeling of plant species distribution. Plant Ecol. 1999, 143, 107-122. [CrossRef]

68. Hosmer, D.W.; Lemeshow, S.; Sturdivant, R.X. Wiley Series in Probability and Statistics. In Applied Logistic Regression; John Wiley \& Sons: Hoboken, NJ, USA, 2013.

69. Demšar, J. Statistical Comparisons of Classifiers over Multiple Data Sets. J. Mach. Learn. Res. 2006, 7, 1-30.

70. Hothorn, T.; Hornik, K.; Wiel, M.A.v.d.; Zeileis, A. A Lego System for Conditional Inference. Am. Stat. 2006, 60, 257-263. [CrossRef]

71. Benjamini, Y.; Hochberg, Y. Controlling the False Discovery Rate: A Practical and Powerful Approach to Multiple Testing. J. R. Stat. Society. Ser. B (Methodol.) 1995, 57, 289-300. [CrossRef]

72. Goetz, J.; Brenning, A.; Marcer, M.; Bodin, X. Modeling the precision of structure-from-motion multi-view stereo digital elevation models from repeated close-range aerial surveys. Remote. Sens. Environ. 2018, 210, 208-216. [CrossRef]

73. Knevels, R.; Petschko, H.; Proske, H.; Leopold, P.; Maraun, D.; Brenning, A. Event-Based Landslide Modeling in the Styrian Basin, Austria: Accounting for Time-Varying Rainfall and Land Cover. Geosciences 2020, 10, 217. [CrossRef]

74. Steger, S.; Brenning, A.; Bell, R.; Glade, T. The propagation of inventory-based positional errors into statistical landslide susceptibility models. Nat. Hazards Earth Syst. Sci. 2016, 16, 2729-2745. [CrossRef]

75. Szumilas, M. Explaining Odds Ratios. J. Can. Acad. Child Adolesc. Psychiatry 2010, 19, 227-229.

76. Tasser, E.; Mader, M.; Tappeiner, U. Effects of land use in alpine grasslands on the probability of landslides. Basic Appl. Ecol. 2003, 4, 271-280. [CrossRef]

77. Petschko, H.; Brenning, A.; Bell, R.; Goetz, J.; Glade, T. Assessing the quality of landslide susceptibility maps—Case study Lower Austria. Nat. Hazards Earth Syst. Sci. 2014, 14, 95-118. [CrossRef]

78. Shirzadi, A.; Solaimani, K.; Roshan, M.H.; Kavian, A.; Chapi, K.; Shahabi, H.; Keesstra, S.; Ahmad, B.B.; Bui, D.T. Uncertainties of prediction accuracy in shallow landslide modeling: Sample size and raster resolution. CATENA 2019, 178, 172-188. [CrossRef]

79. Biszak, E.; Biszak, S.; Timár, G.; Nagy, D.; Molnár, G. Historical topographic and cadastral maps of Europe in spotlight-Evolution of the MAPIRE web portal. In Proceedings of the 12th International Workshop on Digital Approaches to Cartographic Heritage, Venice, Italy, 26-28 April 2017; Volume 12, pp. 204-208. 
80. Gingrich, S.; Niedertscheider, M.; Kastner, T.; Haberl, H.; Cosor, G.; Krausmann, F.; Kuemmerle, T.; Müller, D.; Reith-Musel, A.; Jepsen, M.R.; et al. Exploring long-term trends in land use change and aboveground human appropriation of net primary production in nine European countries. Land Use Policy 2015, 47, 426-438. [CrossRef]

81. Krausmann, F.; Gingrich, S.; Haberl, H.; Erb, K.-H.; Musel, A.; Kastner, T.; Kohlheb, N.; Niedertscheider, M.; Schwarzlmüller, E. Long-term trajectories of the human appropriation of net primary production: Lessons from six national case studies. Ecol. Econ. 2012, 77, 129-138. [CrossRef] [PubMed]

82. Bätzing, W. Die Alpen-Tiefgreifende Nutzungsveränderungen als Herausforderung für den Naturschutz [The Alps-Profound changes in human uses present challenges to nature conservation]. Nat. Und Landsch. 2017, 92, 398-406. [CrossRef] 